\title{
Permian ultrafelsic A-type granite from Besar Islands group, Johor, peninsular Malaysia
}

\author{
Azman A Ghani ${ }^{1 *}$, Fatin Izzani Hazad ${ }^{1}$, Azmiah Jamil ${ }^{1}$, Quek Long Xiang ${ }^{1}$, \\ Wan Nur Atiqah Wan Ismail ${ }^{2}$, Sun-Lin Chung ${ }^{3}$, Yu-Ming Lai ${ }^{3}$, Muhammad \\ Hatta Roselee ${ }^{1}$, Nur Islami ${ }^{1}$, Kyaw Kyaw Nyein ${ }^{1}$, Meor Hakif Amir Hassan ${ }^{1}$, \\ MOHD FARID ABU BAKAR ${ }^{4}$ and MoHD ROzI UMOR ${ }^{5}$ \\ ${ }^{1}$ Department of Geology, University of Malaya, 50603, Kuala Lumpur, Malaysia. \\ ${ }^{2} J$ Resources Sdn. Bhd. P.O. Box 49, 27207 Kuala Lipis Pahang, Malaysia. \\ ${ }^{3}$ Department of Geosciences, National Taiwan University, Taipei, Taiwan. \\ ${ }^{4}$ SapuraKencana Petroleum Bhd, Kuala Lumpur, Malaysia. \\ ${ }^{5}$ Science 83 Technology Faculty, University Kebangsaan Malaysia, 43600 Bangi, \\ Selangor, Malaysia. \\ *Corresponding author.e-mail: azmangeo@yahoo.com
}

The granitic rocks of the peninsula have traditionally been divided into two provinces, i.e., Western and Eastern provinces, corresponding to S- and I-type granite respectively. The Western Province granite is characterised by megacrystic and coarse-grained biotite, tin-mineralised, continental collision granite, whereas, the Eastern Province granite is bimodal I-type dominated by granodiorite and associated gabbroic of arc type granite. This paper reports the occurrence of an A-type granite from peninsular Malaysia. The rocks occur in the Besar, Tengah, and Hujung islands located in the southeastern part of the peninsula. The granite is highly felsic with $\mathrm{SiO}_{2}$ ranging from $75.70 \%$ to $77.90 \%$ (differentiation index $=94.2-97.04$ ). It is weakly peraluminous (average ACNK=1.02), has normative hypersthene $(0.09-2.19 \%)$ and high alkali content $(8.32-8.60 \%)$. The granites have many A-type characteristics, among them are shallow level of emplacement, high $\mathrm{Ga}, \mathrm{Fe}_{\mathrm{T}} / \mathrm{MgO}$ and low $\mathrm{P}$, $\mathrm{Sr}$, $\mathrm{Ti}, \mathrm{CaO}$ and $\mathrm{Nb}$. Calculated zircon saturation temperatures for the Besar magma ranging from $793^{\circ}$ to $806^{\circ} \mathrm{C}$ is consistent with high temperature partial melting of a felsic infracrustal source which is taken as one of the mechanisms to produce A-type magma. The occurrence of the A-type granite can be related to the extensional back arc basin in the Indo-China terrane during the earliest Permian.

\section{Introduction}

A-type granites were first distinguished by Loiselle and Wones (1979) as granite with alkaline and anhydrous affinities and generated in an 'anorogenic' setting. With respect to I- and S-type granitoids, the A-types are characterised by their relatively high alkali and low $\mathrm{CaO}$ contents (at
$\left.\mathrm{SiO}_{2}=70 \%: \mathrm{Na}_{2} \mathrm{O}+\mathrm{K}_{2} \mathrm{O}=7-11 \%, \mathrm{CaO}<1.8 \%\right)$ and high $\mathrm{FeO}_{\mathrm{T}} / \mathrm{MgO}=8-80$. It often has elevated halogen, particularly $\mathrm{F}$ contents $(\mathrm{F}=0.05-1.7 \%)$, can contain water up to a few $\%$ and is characterised by low water and oxygen fugacity (Loiselle and Wones 1979). It can be met aluminous or even peraluminous (Collins et al. 1982). Several petrogenetic models for A-type granites have

Keywords. Ultrafelsic granite; A-type granite; peninsular Malaysia; Johor island; eastern belt. 
been proposed as summarised by Bonin (2007), including:

- extensive fractional crystallization from mantlederived mafic magmas (Turner et al. 1992);

- interaction of mantle-derived magmas and overlying crustal rocks (Kerr and Fryer 1993);

- anatexis of middle or lower crustal source rocks (Collins et al. 1982; Creaser et al. 1991); and

- metasomatism of granitic magmas (Taylor et al. 1981).

Studies show that A-type granite occurs in a wide variety of tectonic settings which include transcurrent shear zones (Nironen et al. 2000; Lauri et al. 2006); extensional regime (Smith et al. 1977; Mahood and Hildreth 1986; Capaldi et al. 1987; Johnson et al. 1989; Key 1989); reactivation of transcurrent shear zones within uplifts and swells (Bonin et al. 1987, 1998; Rämö and Haapala 1995; Christiansen et al. 2002), and within-plate (Gagnevin et al. 2003; Bonin et al. 2004; Tucker et al. 2001) settings.

Granitic rocks form about $60 \%$ of the total land area of peninsular Malaysia. They can be divided into two contrasting granite types based on mineralogy and geochemistry. They are: (1) Stype Western Belt and (2) Eastern Belt composed mainly of I-type (with minor S-type). Both granite provinces are separated by a paleo-suture known as the Bentong-Raub-Suture which represents the closure of the Tethys ocean during the Late Permian to Early Triassic. The Western Belt granite is tin-bearing, monzo- to syenogranite \pm granodiorite with $\mathrm{SiO}_{2}$ content ranging from 66 to $75 \%$. The Eastern Belt granite is bimodal and consists of granodioritic (+ monzogranite) and associated with minor gabbroic-dioritic intrusions with $\mathrm{SiO}_{2}$ contents $68-73 \%$ and $55-60 \%$, respectively. This paper reports the occurrence of A-type granite from the Besar island off the southeastern coast of peninsular Malaysia. We will discuss the implications of the A-type granite to the tectonism of peninsular Malaysia.

\section{General geology and tectonic setting}

The granitoids of southeast Asia have been grouped into north-south elongate provinces: (i) Western (southwest Thailand-east Myanmar) granite provinces, (ii) Eastern provinces (east Malaya), (iii) Main Range provinces (south Thailand-west of peninsular Malaysia and (iv) Northern provinces (N Thailand) (Hutchison 1973, 1977; Mitchell 1977; Cobbing et al. 1992) (figure 1). Two of the provinces exposed in peninsular Malaysia are the Eastern and Main Range provinces, also known as Eastern and Western Belt granites, respectively (figure 2). They are separated by the Bentong-Raub suture (Metcalfe 2000) and show very contrasting petrological, age, and geochemical characteristics. The Main Range granite is generally younger, i.e., 198-220 Ma (Liew and Mc Culloch 1985; Liew and Page 1985; Searle et al. 2012; Ghani et al. 2013a) and has been regarded as collisional granite. The Eastern granite province consists of Triassic to Permian granitoids (220-280 Ma) intruded by swarms of basaltic dykes (Haile et al. 1983; Ghani 2000a, b; Ghani et al. 2013b). The granitoids occur contemporaneous with volcanic rocks of the same age (Ghani et al. 2013c, 2014). The age generally becomes older eastward from the Bentong-Raub suture, with the oldest ages recorded from the eastern coastal granite outcrops such as the Maras Jong, Kuantan, and Bari granites (Liew 1983; Oliver et al. 2013). High $\mathrm{SiO}_{2}$ granites for both provinces are usually restricted to veins and high-level pods or dykes. However, in unusual cases, the high $\mathrm{SiO}_{2}$ granite can occur as small plutons characterised by homogeneous, enclave-free, and leucocratic rock. One example of a pluton sized high $\mathrm{SiO}_{2}$ granite is the Besar granite. The granite is exposed in three islands, i.e., Besar, Tengah, and Hujung islands. The islands (referred to as the Besar Island Group in this paper) are part of Johore state, in the southern part of peninsular Malaysia. The islands are situated about $13 \mathrm{~km}$ off the peninsular Malaysia mainland (figure 3). The total area of granitic rocks in the three islands is about $4 \mathrm{~km}^{2}$. The granite is ultrafelsic with an average $\mathrm{SiO}_{2}$ content of $\sim 76.5 \%$ and high K-feldspar + quartz content $\sim>70 \%$.

Regionally, the Johore islands expose the eastern most plutonic and volcanic rocks of peninsular Malaysia (figure 3). The archipelago is gazetted as a National Park which consists of beautiful islands such as Tioman, Aur, Pemanggil, Tinggi, and Sibu (Khoo 1974; Ghani et al. 1999; Mohd Basri 2002; Ghani and Mohd Farid 2004; Ghani 2006, 2008, 2009; Ghani and Azmi 2008). A variety of igneous rocks are exposed on these islands, ranging from basic to felsic plutonic rock and pyroclastic to felsic and intermediate volcanic lava. Both Sibu and Tinggi islands are made up of pyroclastic volcanic types whereas intermediate to basic plutonic rocks (dioritic to gabbroic in composition) dominate the Pemanggil and Aur islands. The age of the plutonic and volcanic rocks in the islands is poorly known. Biotite feldspar granites from Tioman Island off the east coast of Malaysia yield a zircon age of $80 \pm 1$ Ma (Searle et al. 2012). Ar-Ar age of biotite of the dioritic rocks from Pemanggil Island (Ghani et al. 2014) gives about $78 \pm 2$ Ma. Both ages suggest that the Cretaceous magmatism is common within this area. $\mathrm{Ar}-\mathrm{Ar}$ ages from Sibu volcanoclastic and Tinggi volcanic lavas give ages of $\sim 300 \mathrm{Ma}$ 


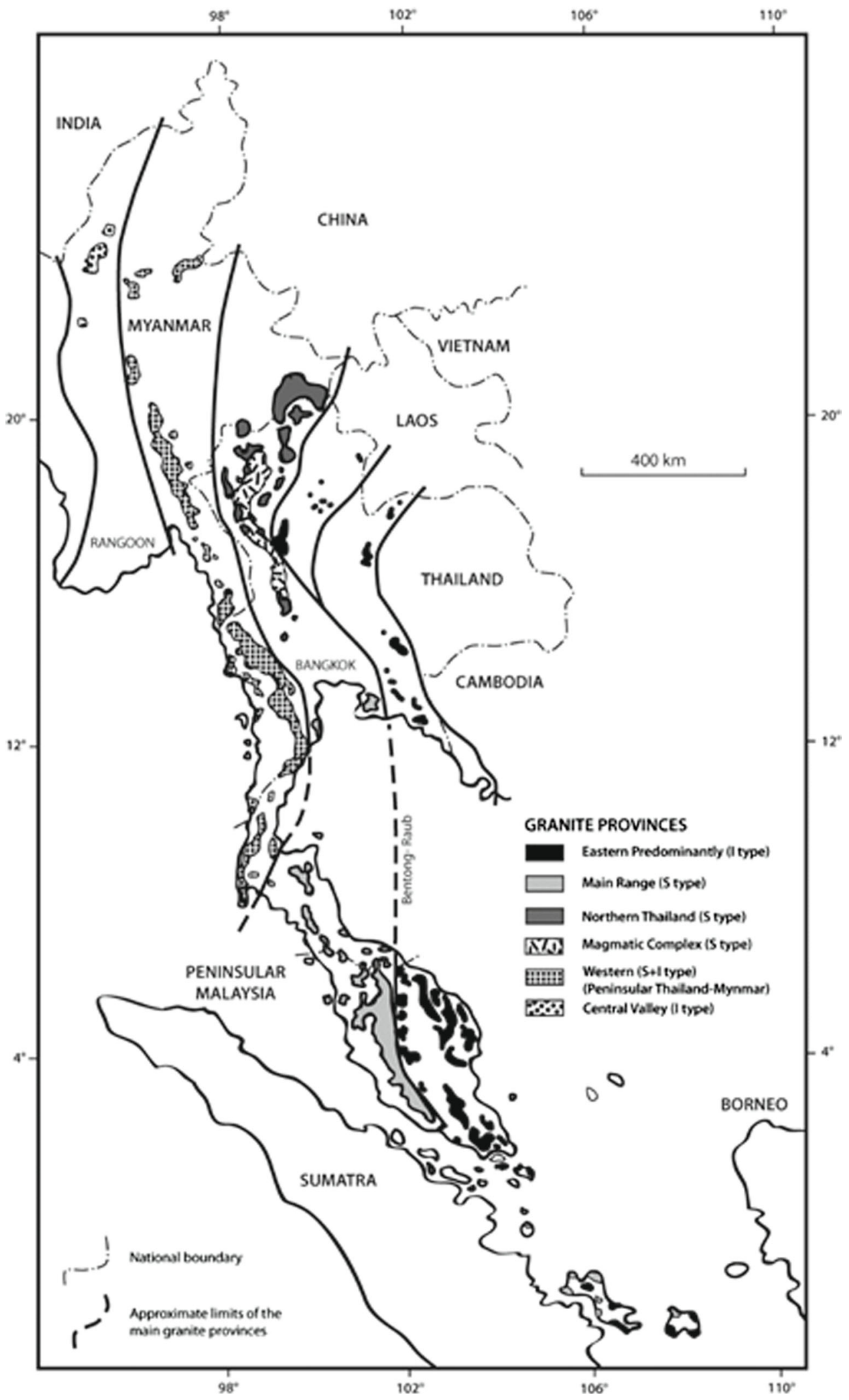

Figure 1. Subdivision of granitoids from the southeast Asia Tin Belt (modified from Cobbing et al. 1992).

and $\sim 100$ Ma, respectively (Oliver et al. 2013; Ghani et al. 2014). U-Pb zircon dated Sibu tuff or volcanoclastic conglomerate at $274.8 \pm 5.2 \mathrm{Ma}$.
Ghani et al. (1999) reported evidence for an older garnet-bearing granite series in the eastern part of the Tioman Island. 


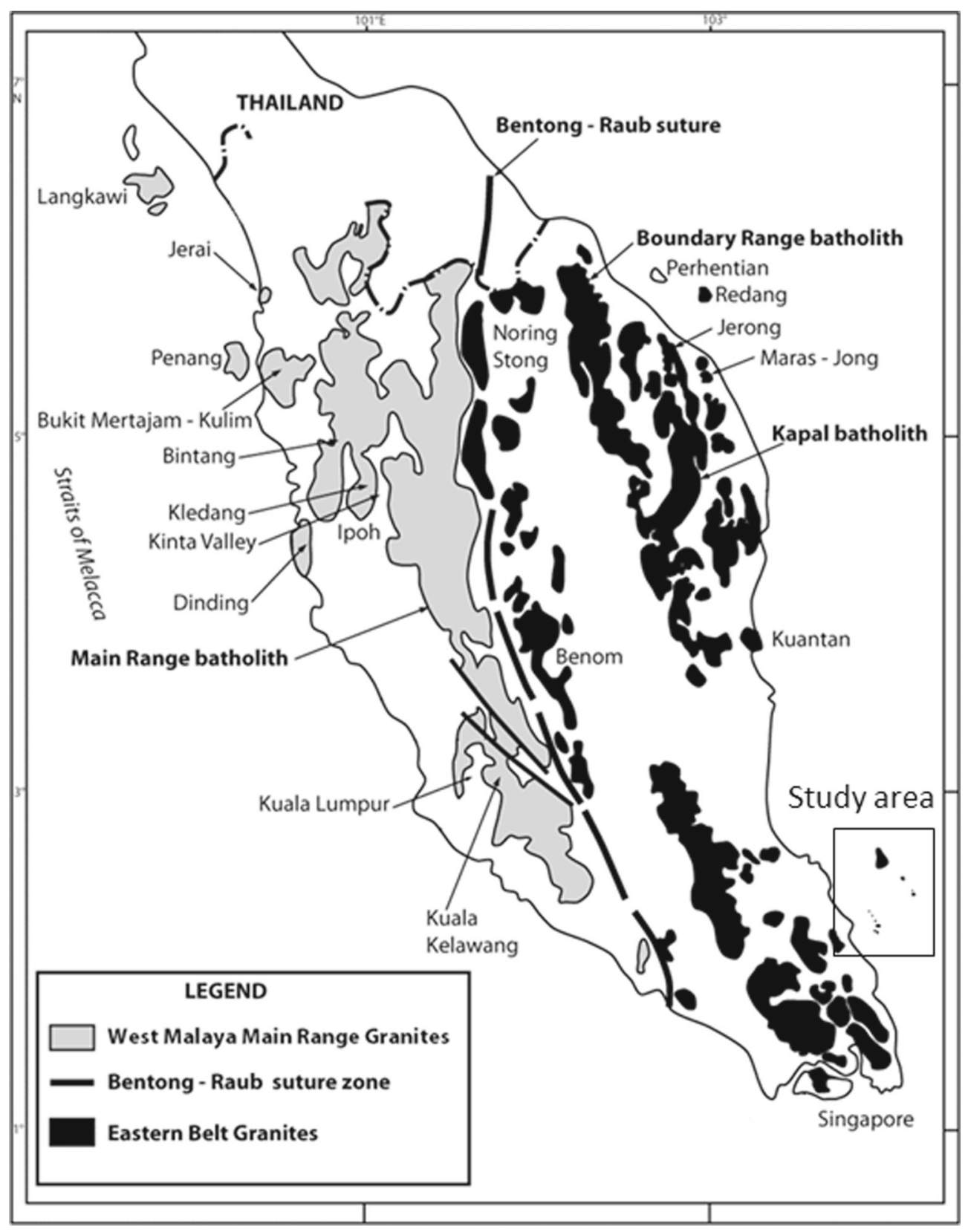

Figure 2. Subdivision of granites from peninsular Malaysia showing the Eastern and Western Belts. Small box is the study area.

The Besar Island Group is made up of biotite granite, leucogranite, mafic dykes, and metasedimentary rocks (figure 4). The granitic rock is homogeneous, medium to coarse-grained, equigranular and is devoid of xenoliths and other enclaves. The metasedimentary rocks consist of an interbedded sequence of phyllite and quartzite, both varying in thickness from 0.5 to $5 \mathrm{~cm}$. The granite intrudes the metasedimentary formation and this is evident from a large metasedimentary raft that occurs to the south of Tengah Island, and is intruded by a swarm of granitic veins and mafic dykes (figure 5a and b). The veins show an irregular thickness from $5 \mathrm{~mm}$ to $5 \mathrm{~cm}$ (figure $5 \mathrm{a}$ ). The granites have been intruded by a series of northeastsouthwest trending mafic dykes with average thicknesses ranging from 0.5 to $2 \mathrm{~m}$ (figure $5 \mathrm{c}$ ). A leucogranitic xenolith is found in the pyroclastic volcanic ash Sibu Island, $2 \mathrm{~km}$ south of the study area (figure $3 \mathrm{~d}$ ). The xenolith has a similar texture and mineralogy when compared to the Besar granite. If the granite represents part of the Besar Granite Group, then it appears that the granite is possibly older than Permian. 

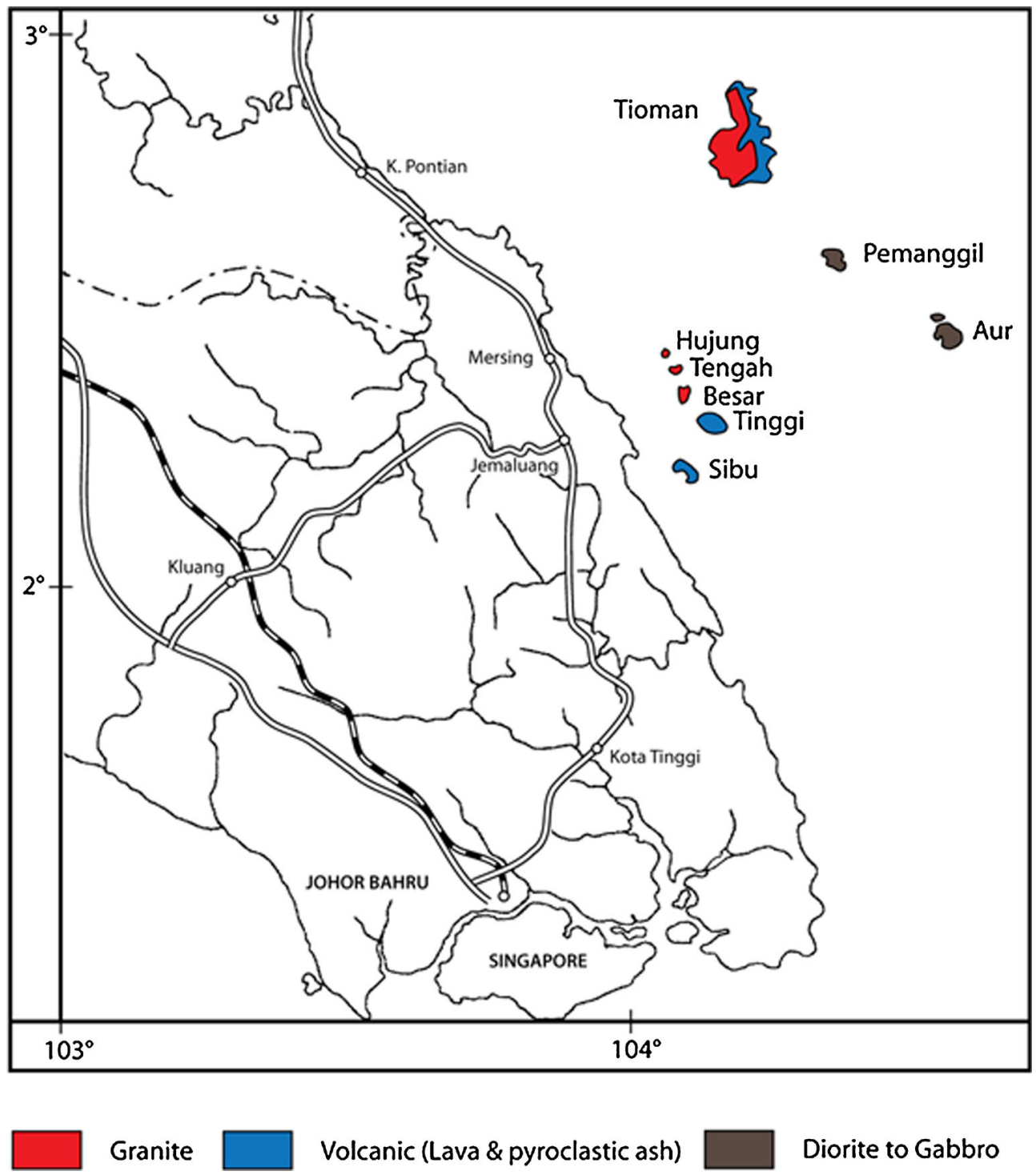

Diorite to Gabbro

Figure 3. Geological map of the south Johor islands. Location map showing the southern part of peninsular Malaysia and the geology of the Johor islands.

\section{Petrology}

The main granite from the three islands (with average \%) consists of K-feldspar (40\%), plagioclase $(20 \%)$, quartz $(35 \%)$, biotite $(<5 \%)$, amphibole (trace), apatite (trace), zircon (trace), sericite, and chlorite. Some of the leucogranites exhibit a porphyritic texture with K-feldspar, plagioclase, and quartz as the main phenocrystic phases. The phenocrysts always have irregular outlines bordered by micro-granophyric texture. Quartz sometimes displays embayed texture and resorbed outline resulting in skeletal shape.

Plagioclase $\left(\mathrm{An}_{4-12}\right)$ is equigranular, subhedral to anhedral and usually occurs as clusters and may represent early plagioclase, which crystallised from the melt. Some plagioclases have cracked and corroded cores and these crystals are usually accompanied by zoned crystals. No cores with higher anorthite contents have been identified. Sericite is present mainly at the centre of the mineral. The main alkali feldspar type isperthitic orthoclase sometimes exhibit simple twinning. The crystals are usually bigger in size compared to quartz and plagioclase.

Granophyric intergrowths can be seen extensively in the Tengah and Hujung granite samples (figure 6). Quartz in the granophyric texture displays various shapes from rounded elongate to square to worm-like to tiny rounded shapes (figure $6 \mathrm{~b}$ and $\mathrm{d}$ ). The texture sometimes radiates from plagioclase and alkali feldspar. There are two types of quartz present: (i) large anhedral quartz grains displaying shadowy extinction indicating 


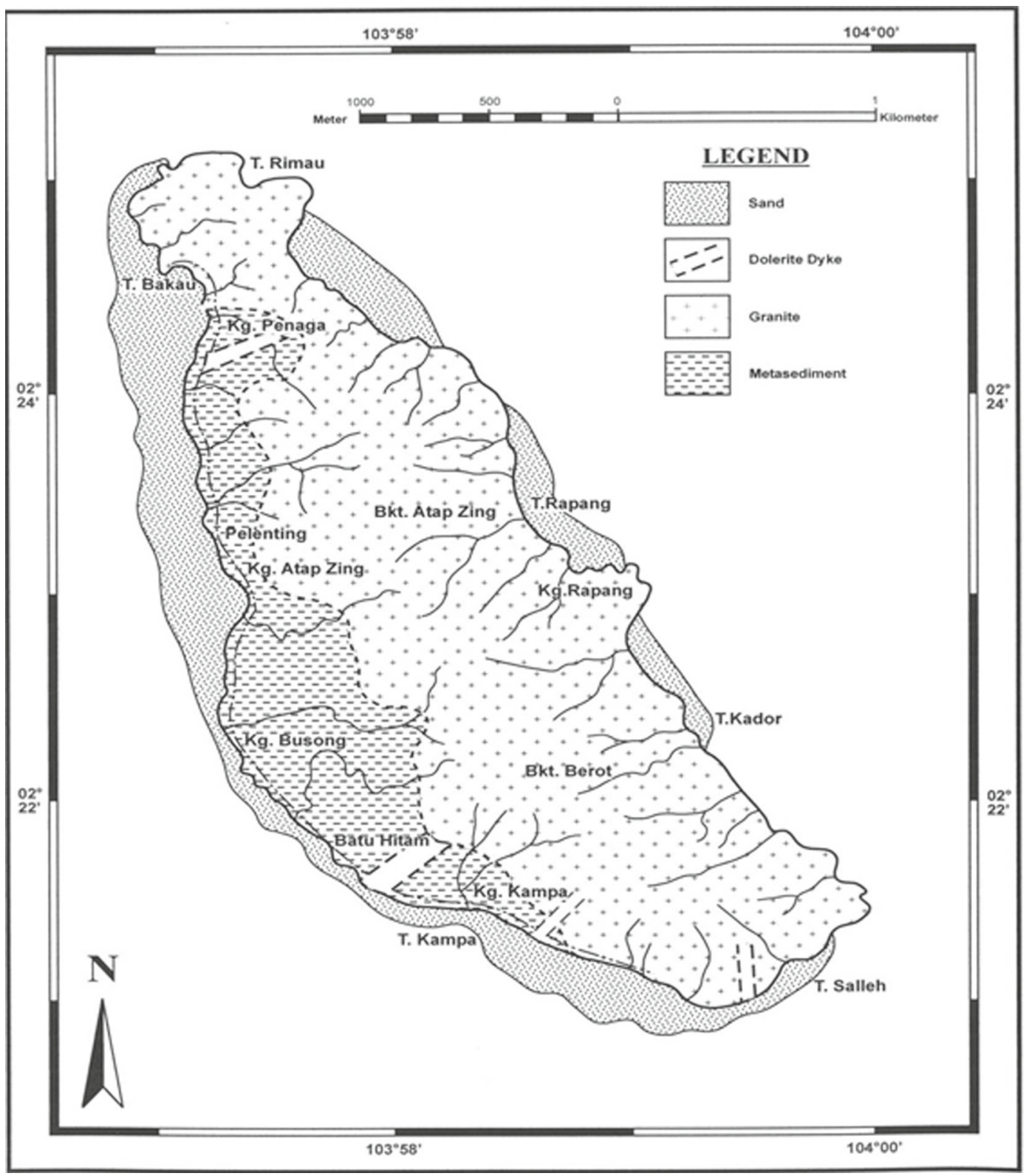

Figure 4. Detailed geological map of the Besar Island. The Besar Island is the biggest island among the three islands. Other two islands, Tengah and Hujung also have the same geology.

strain (figure 6a and c) and (ii) smaller anhedral quartz associated with granophyric intergrowth. Sometimes, they form a zone of quartz blebs at the margins of plagioclase (figure 6e). The type (i) quartz usually has embayed texture especially if the crystal occurs adjacent to the intergrowth (figure 6a, c and d). Muscovite occurs as small or tiny crystals $(0.1 \mathrm{~mm}$-wide and up to $0.4 \mathrm{~mm}$ long) associated with heavily sericitised parts of plagioclase. Sometimes, the tiny flakes are welloriented at the centre of plagioclase, suggesting that the minerals were developed along the cracks. These textural relationships suggest that the muscovite is not primary but altered from plagioclase.
The main mafic phase is biotite and occurs less than $5 \%$ in the rock. The pleochroic scheme is $\mathrm{X}=$ dark brown and $\mathrm{Y}=$ straw yellow. The texture suggests that the mineral was early in origin because it occurs as inclusions in other essential minerals. Alteration of biotite to chlorite is common and developed mainly along the biotite cleavage. Occasionally, secondary muscovite crystals can be seen developed in the biotite cleavage. The Besar granite does not contain any amphibole as in many A-type granites reported elsewhere (King et al. 1997). However, there are traces of a greenish mineral, which appears similar to the green amphibole, but this needs to be confirmed using EPMA as the crystals are too small to be identified using 

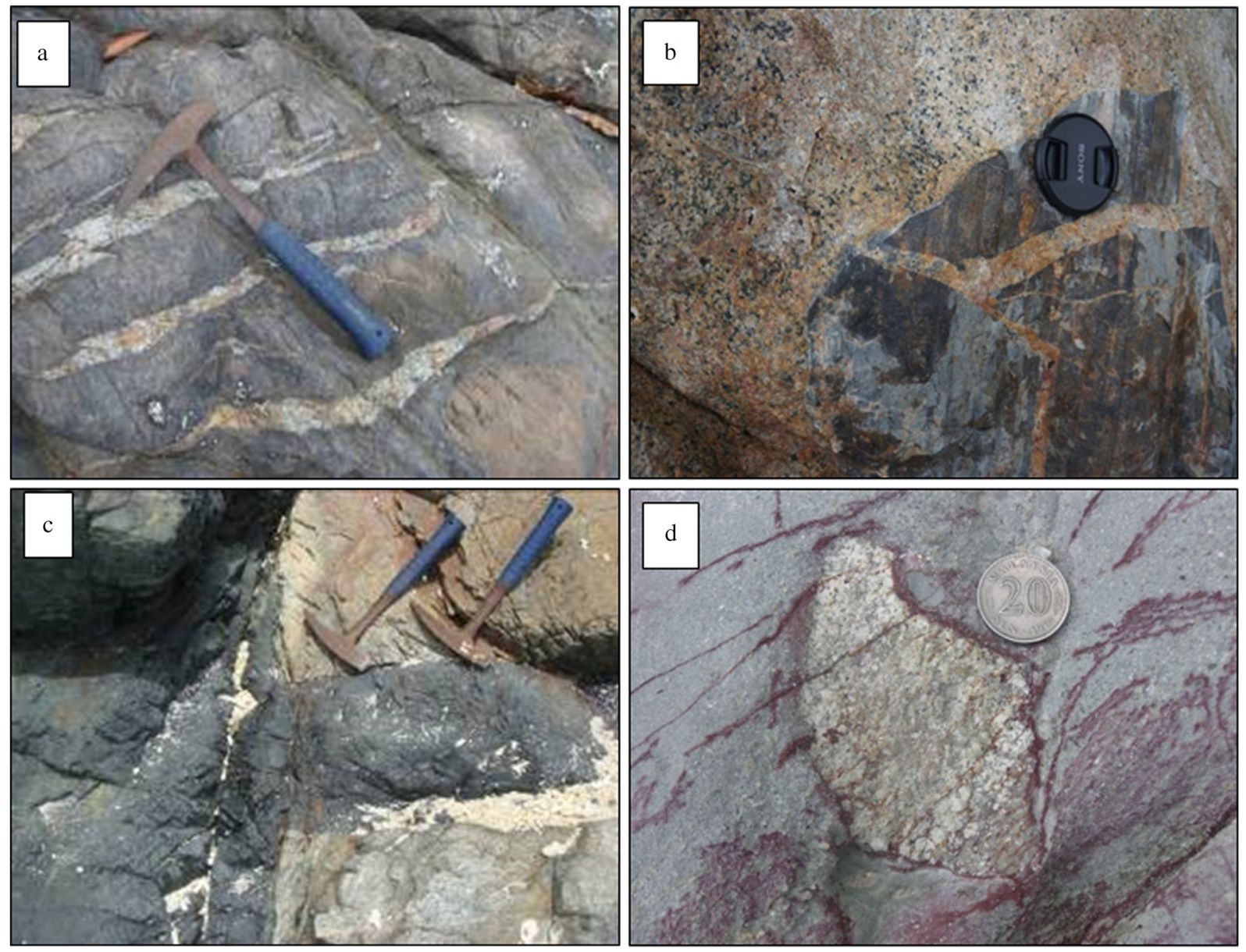

Figure 5. Various field photos of Besar, Tengah and Hujung islands. (a) Swarms of parallel granitic dykes and veins intruded into the metasediments raft at Tengah island; (b) contact between granite (left) and metasediments block at the Tengah island; (c) enclave of mafic dyke in the leucogranite of Hujung Island. Below the enclave is the contact between the dyke proper and the leucogranite; (d) leucogranite block found in the nearby Ash tuff formation of the Sibu Island (south of Besar Island). The tuff dated as 296-299 Ma (Ghani et al. 2014).

ordinary light microscope (figure 6d). The crystal occurs either interstitially or as individual anhedral shapes.

\section{Geochronology}

Two samples, one each from Besar (sample BES5) and Tengah (sample TG4) islands have been selected for $\mathrm{U}-\mathrm{Pb}$ zircon dating. The analyses have been done at the Department of Geoscience, National Taiwan University, Taiwan. Zircons were separated from rock samples (up to $5 \mathrm{~kg}$ per sample) using conventional heavy-liquid and magnetic separation techniques. The zircons were cast with zircon standards in epoxy mounts that were polished to section the crystals for analysis. Cathodo luminescence images were taken for examining the internal structures of individual zircon grains and selecting suitable positions for $\mathrm{U}-\mathrm{Pb}$ isotope analyses, which were performed using a New Wave
UP213 laser ablation system combined with an Agilent 7500s quadrupole ICPMS (inductively coupled plasma mass spectrometer).

The zircons from both samples were euhedral to subhedral and mostly showed long to short prismatic forms. However, the zircon crystals from TG4 sample were larger compared to the zircons from BES 5 (figure 7). Majority of the zircons were transparent, colourless to pale brown and showed oscillatory zoning indicative of magmatic growth. Thus, the interpretation of zircon $\mathrm{U}-\mathrm{Pb}$ isotope data is simple and the obtained ages are interpreted as representing the crystallization time of the zircons or the emplacement age of the host rocks.

The $\mathrm{U}-\mathrm{Pb}$ age results for both samples are shown in figure 8 and table 1 , all the mean ${ }^{206} \mathrm{~Pb} /{ }^{238} \mathrm{U}$ ages are given at $95 \%$ confidence level for both samples. All of the analyses are concordant, and the ${ }^{206} \mathrm{~Pb} /{ }^{238} \mathrm{U}$ ages for BES 5 scatter between 264 and $336 \mathrm{Ma}$ giving a weighted mean age of 

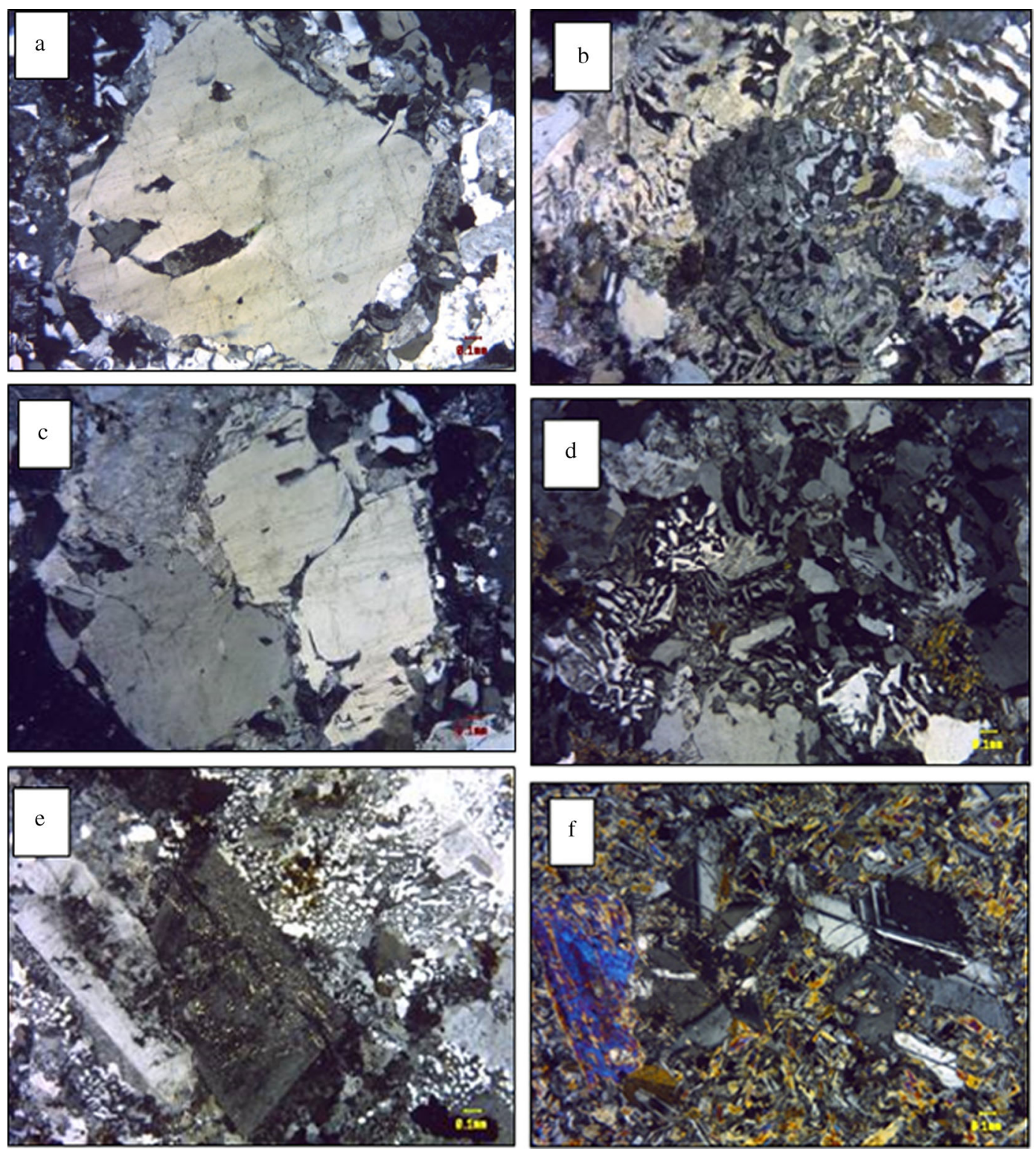

Figure 6. Photomicrograph of the granitic rocks from the Besar, Tengah and Hujung islands. (a) Euhedral shape of quartz crystal. Coarse grained biotite granite; (b) coarse wormy K-feldspar and quartz intergrowth. Coarse grained biotite granite; (c) Quartz gleomerocrysts showing embayed texture. Coarse grained biotite granite; (d) coarse wormy K-feldspar and quartz intergrowth. Coarse grained biotite granite; (e) plagioclase gleomerocryst in leucogranite surrounded by microgranophyric intergrowth. Note the margin of the plagioclase show irregular margin invade by granophyric intergrowth; (f) plagioclase and clinopyroxene occur as a phenocrystic phase in dolerite sample. Plagioclase gleomerocryst (2 or more plagioclase phenocryst crystal cluster together) is quite common in the dyke.

$281.7 \pm 2.1$ Ma. For TG4 sample, the ${ }^{206} \mathrm{~Pb} /{ }^{238} \mathrm{U}$ ages plot between 274 and 294 Ma (mean age of $280.1 \pm 2.4 \mathrm{Ma})$, with one spot giving extremely high age (1141 Ma).

\section{Geochemistry}

\subsection{Methods}

Nine representative granite samples were collected from the Hujung (2), Tengah (2) and Besar (5) islands. All samples were crushed to a fine powder at the Department of Geology, University of Malaya, Kuala Lumpur, Malaysia. The whole-rock compositions were determined at Acme Analytical Laboratories in Vancouver, Canada. Major elements were determined by X-ray fluorescence (XRF) using a Philips PW 1404/10 X-ray spectrometer by fusing the samples with lithium tetraborate and casting into glass discs. Precision was of $2-5 \%$ for major elements, except for $\mathrm{Mn}$ and $\mathrm{P}(2.5-5 \%)$. Calibration was done with international standards PM-S and WS-E (Govindaraju 


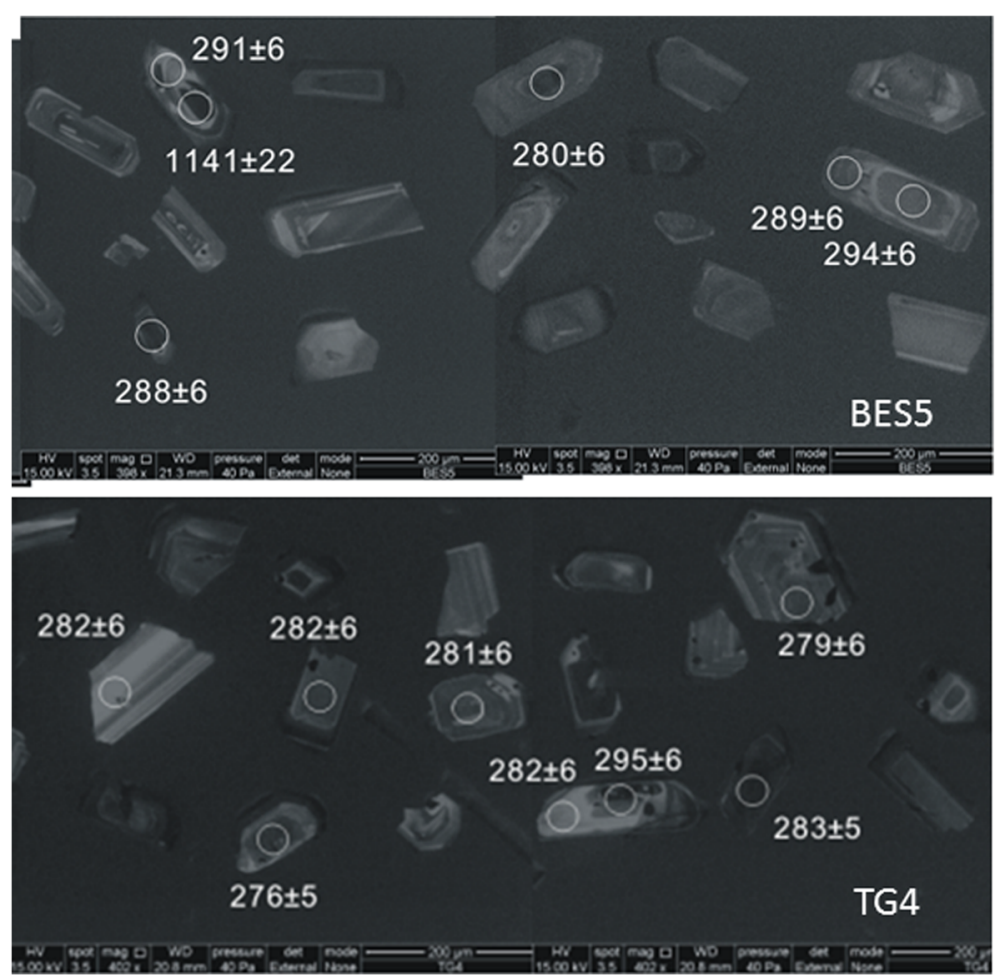

Figure 7. Represantative of CL image of zircons for samples BES5 and TG4.

et al. 1994). Trace and rare earth elements were also analysed at the same Lab using ICP-MS. Trace and rare earth and refractory elements were determined by ICP mass spectrometry following a Lithium metaborate/etraborate fusion and nitric acid digestion of a $0.2 \mathrm{~g}$ sample. Precision for all trace elements ranged between 2 and $4 \%$.

\subsection{Results}

All granite samples from the Besar granite are high in silica and alkalis, with $\mathrm{SiO}_{2}$ ranging from 75.70 to 77.90 wt\% and total $\mathrm{K}_{2} \mathrm{O}+\mathrm{Na}_{2} \mathrm{O}$ varying from 8.32 to $8.6 \mathrm{wt} \%$ (table 2). The granite is weakly peraluminous, with $\mathrm{A} / \mathrm{CNK}$ value ranging from 1 to 1.16 (average 1.02). Interestingly, all the samples have normative hypersthene, ranging from 0.09 to $2.3 \%$. Differentiation index for all granite samples ranges from 94.2 to 97.04 . The granite has low $\mathrm{Al}_{2} \mathrm{O}_{3}$ and $\mathrm{K}_{2} \mathrm{O}$ compared with the Main Range S-type granite of peninsular Malaysia. $\mathrm{On} \mathrm{Rb}$ vs. $\mathrm{Y}+\mathrm{Nb}$ and $\mathrm{Rb}$ vs. $\mathrm{Ta}+\mathrm{Yb}$ diagrams (Pearce et al. 1984), all samples plot in within plate granite field (figure 9). All rock samples plot in the A-type field in $\mathrm{FeOt} / \mathrm{MgO}$ vs. $\mathrm{Zr}+\mathrm{Nb}+$ $\mathrm{Ce}+\mathrm{Y}$, (b) $\left(\mathrm{Na}_{2} \mathrm{O}+\mathrm{K}_{2} \mathrm{O}\right) / \mathrm{CaO}$ vs. $\mathrm{Zr}+\mathrm{Nb}+\mathrm{Ce}+\mathrm{Y}$, (c) $\mathrm{K}_{2} \mathrm{O} / \mathrm{MgO}$ vs. $10000 * \mathrm{Ga} / \mathrm{Al}$, (d) $\mathrm{FeOt} / \mathrm{MgO}$ vs. $10000 * \mathrm{Ga} / \mathrm{Al}$, (e) Ce vs. $10000 * \mathrm{Ga} / \mathrm{Al}$, and (f)
$\mathrm{Y}$ vs. $10000 * \mathrm{Ga} / \mathrm{Al}$ diagrams (figure 10 ) (Collins et al. 1982; Whalen et al. 1987). The Besar samples also plot in the field of ferroan granites (figure 11) following the classification of Frost et al. (2001). In the modified alkali lime index $\left(\mathrm{Na}_{2} \mathrm{O}+\mathrm{K}_{2} \mathrm{O}-\mathrm{CaO}\right)$ vs. $\mathrm{SiO}_{2}$ diagram (figure 12), the Besar granites straddle between alkali calcic and calc alkali fields similar to the A-type Kaffo Valley albiteriebeckite granite, northern Nigeria (Orajaka 1986).

REE profile for the Besar granite is shown in figure 13. A majority of the rocks analysed display a striking uniformity in their REE patterns. Chondrite-normalized REE patterns show enrichment of LREE relative to heavy rare earth elements (HREE) and significant negative Eu anomalies. The total REE for the granite ranges from 268 to $615 \mathrm{ppm}$ which is characteristic of high to highly felsic granite. Another interesting feature of the REE profile is that, although all the analysed samples have very high $\mathrm{SiO}_{2}$, the profile does not show a tetrad effect profile as shown by many other high $\mathrm{SiO}_{2}$ granites elsewhere (Kawabe 1995; Irber 1999; Jahn et al. 2001; Wu et al. 2004; Monecke et al. 2007). This is also evidenced from calculated $\mathrm{TE}_{1,3}$ for all the samples which give the value of $<1.1$ (Irber 1999). The $\mathrm{TE}_{1,3}$ value of the Besar granites range from 1.0-1.09. Compared to the typical A-type granite 

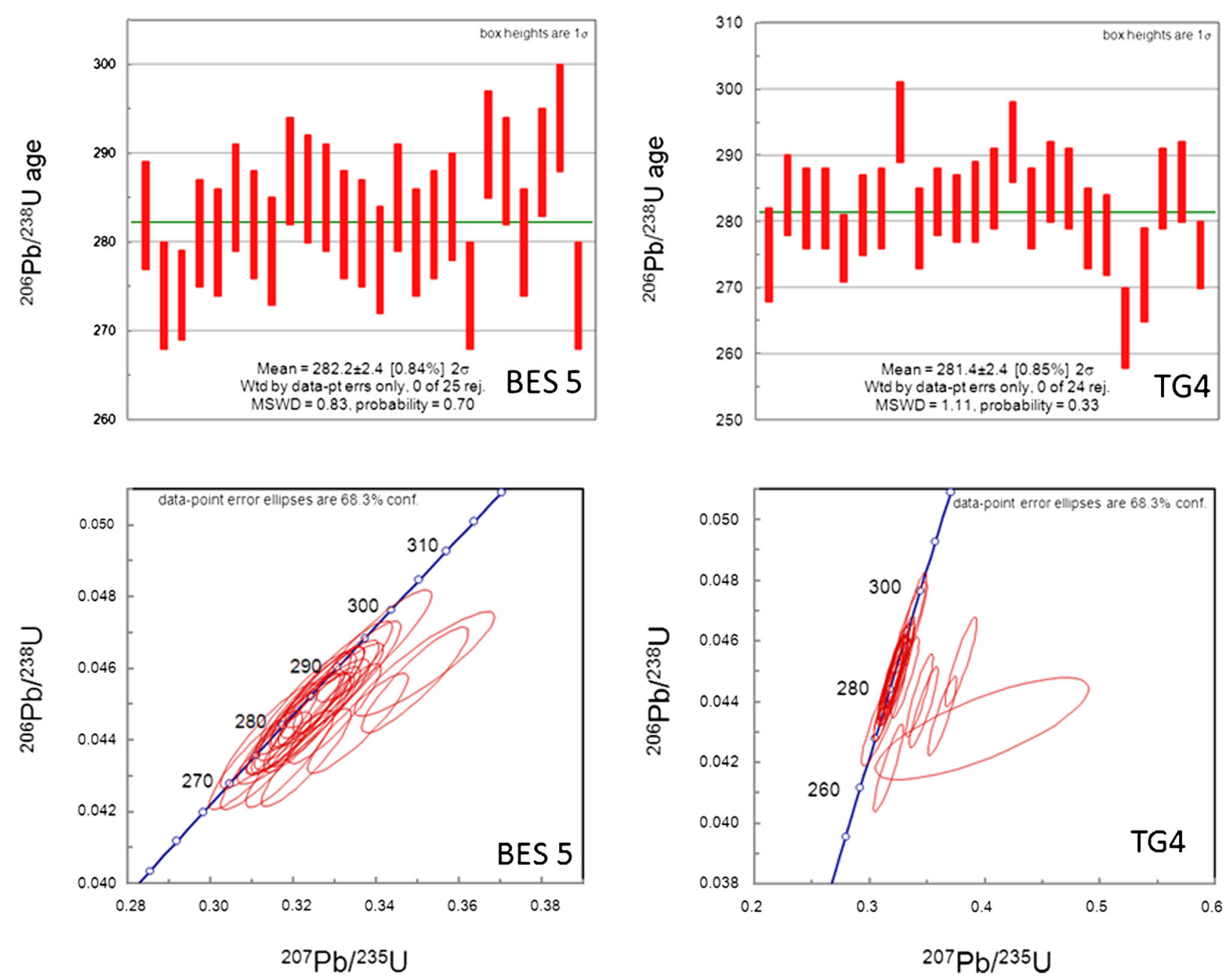

Figure 8. Zircon U-Pb concordia and weighted average diagram for sample (a) TG4 and (b) BES5 from the Besar granites.

(figure 13), the rocks from the study area show slightly higher total REE content and less negative Eu anomaly.

In the spider diagram (figure 14), all the granitic rocks show the characteristic negative anomalies for $\mathrm{Ba}, \mathrm{Nb}, \mathrm{Sr}, \mathrm{P}, \mathrm{Zr}, \mathrm{Eu}$, and $\mathrm{Ti}$, and positive anomalies for Th, Ce, U, K, Pb, La, $\mathrm{Nd}$, and $\mathrm{Sm}$ consistent with the patterns for A-type granites (Collins et al. 1982; Whalen et al. 1987). The troughs at $\mathrm{Sr}$ and $\mathrm{Ti}$ could be related either to the plagioclase and $\mathrm{Fe}-\mathrm{Ti}$ oxides residual or to the early extraction of the $\mathrm{Fe}-\mathrm{Ti}$ phases.

Figure 15 shows $\mathrm{Zr}$ vs. M diagram for the calculated temperature ( $\mathrm{M}$ whole-rock cationic ratios $[(100 \mathrm{Na}+\mathrm{K}+2 \mathrm{Ca}) /(\mathrm{Al} \cdot \mathrm{Si})]$ for the Besar granites. All the samples from the three islands clustered at curve approximately $T=800^{\circ} \mathrm{C}$ and $\mathrm{M}=1.3$ to 1.4. Calculated zircon saturation temperatures from bulk rock compositions yield a temperature range for the Besar magma from $793^{\circ}$ to $806^{\circ} \mathrm{C}$ (Watson and Harrison 1983).

\section{Discussion}

Geochemical study of the Besar granite indicates that the rocks have higher $\mathrm{SiO}_{2}$ compared with other peninsular Malaysia granites and more importantly, they occur in pluton size. In other Malaysian granites, highly felsic plutonic rock $\left(\mathrm{SiO}_{2}>75 \%\right)$ usually occurs as veins oraplopegmatite complexes, small stocks, high-level and secondary variant two-phase granite pods within a granitic pluton or batholith. These types of granite represent a highly evolved residual magma typically associated with tin-tungsten mineralisation, greisen vein systems and are usually associated with high concentrations of $\mathrm{U}$ and $\mathrm{Th}$ and are different from the presently studied granite 


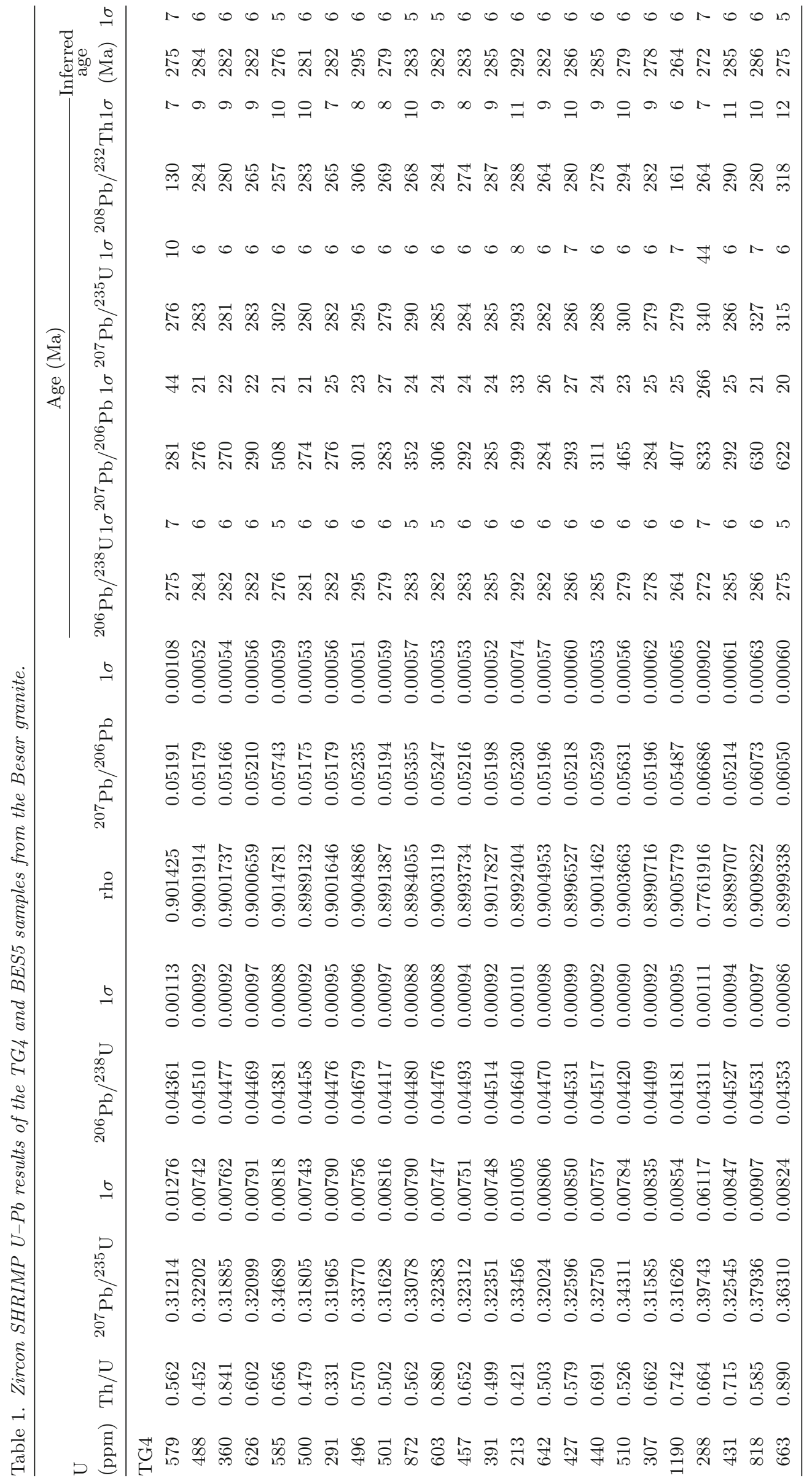




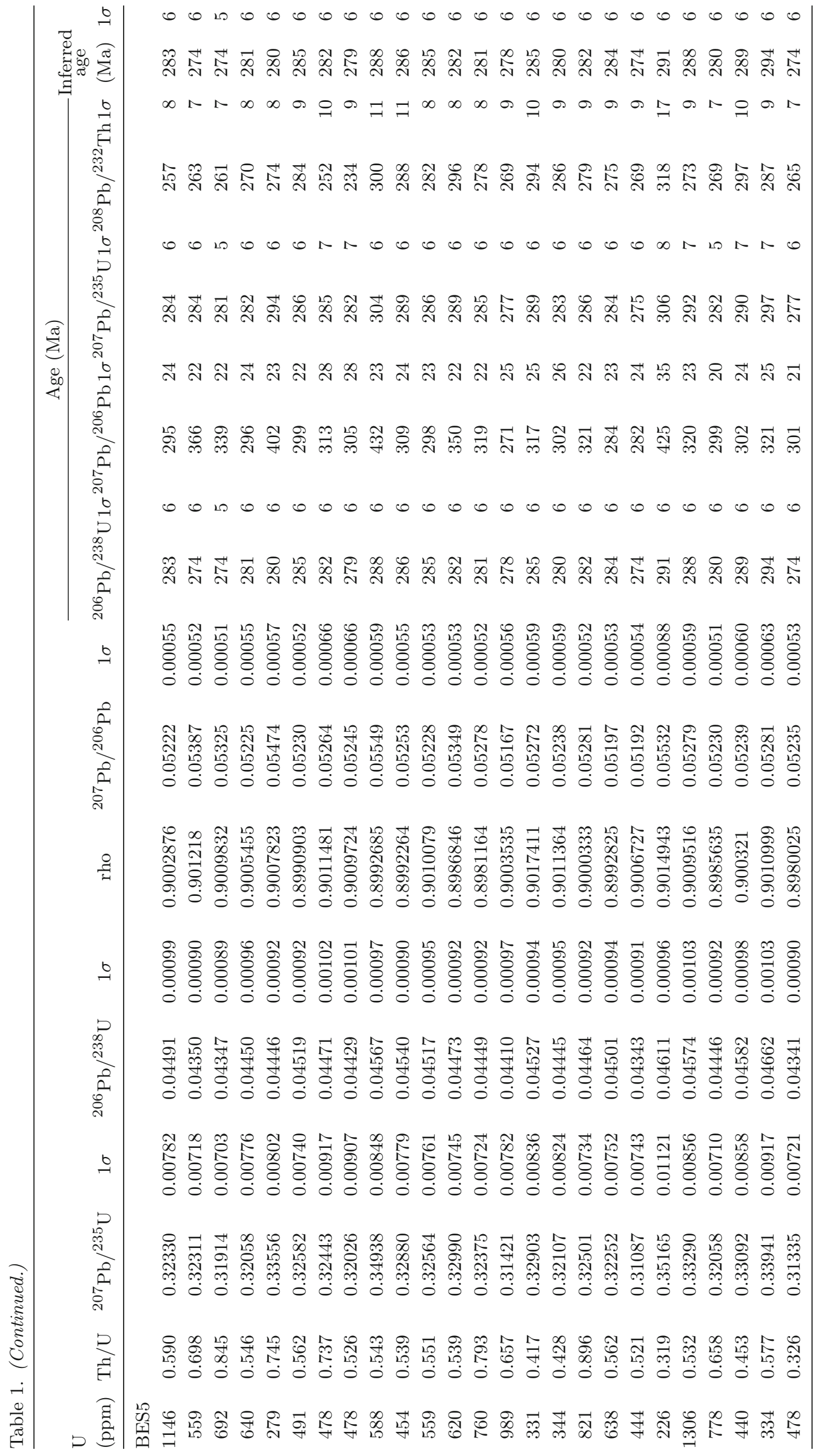



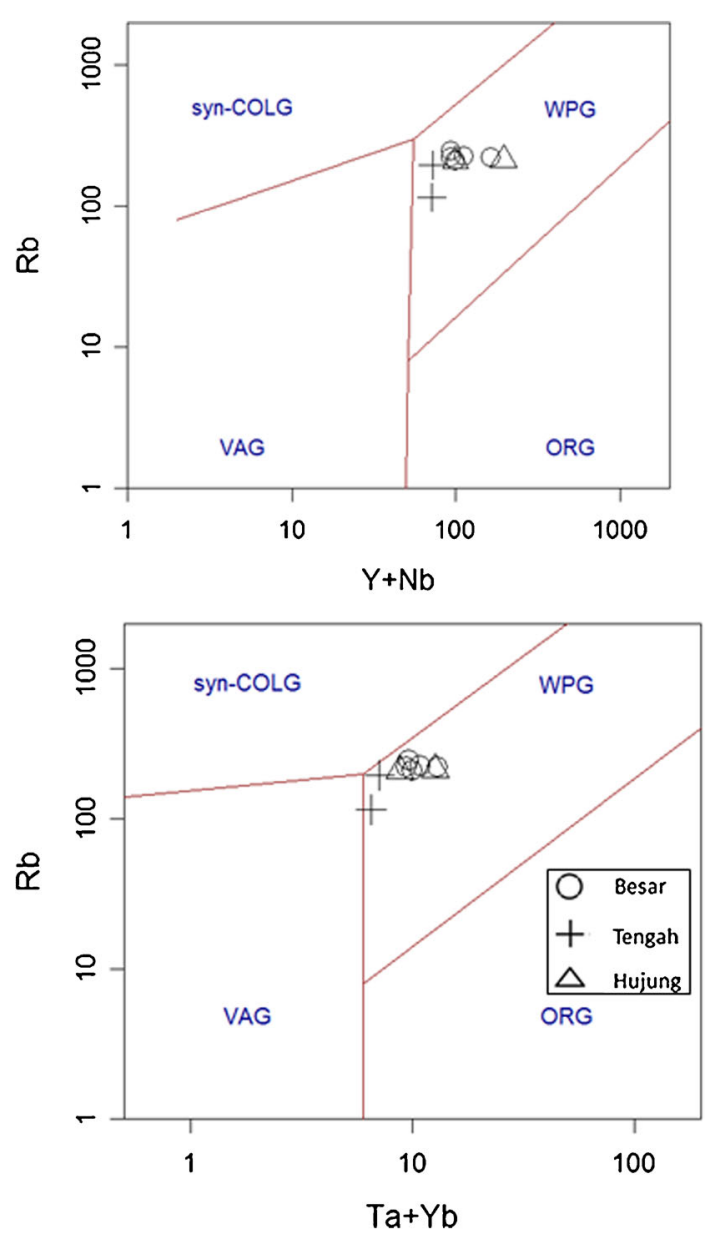

Figure 9. $\mathrm{Rb}$ vs. $\mathrm{Y}+\mathrm{Nb}$ and $\mathrm{Rb}$ vs. $\mathrm{Ta}+\mathrm{Yb}$ for the Besar, Hujung and Tengah granites. In both plots, all samples fall in the within plate (WAG) field. VAG: Volcanic arc granite; Syn-COLG: Syn collision granite; ORG: Orogenic granite (Pearce et al. 1984).

which represents a pluton-sized body of highly felsic magma. Liew (1983) modelled the evolution of the main range granite and suggested that 50-70\% fractionation of parental granodioritic magma is required to achieve the trace element signatures $(\mathrm{Rb}>500 \mathrm{ppm}, \mathrm{Ba}$ and $\mathrm{Sr}<50 \mathrm{ppm})$ of many of the highly felsic plutonic rock from the Western Belt of peninsular Malaysia.

The Besar granitic rock is characterized by homogeneous, equigranular, medium grained granite and is generally devoid of xenoliths and other enclaves. The granites have many A-type characteristics, among them are high $\mathrm{Ga} / \mathrm{Al}, \mathrm{Fe}_{\mathrm{T}} / \mathrm{MgO}$, low $\mathrm{P}, \mathrm{Sr}, \mathrm{Ti}, \mathrm{CaO}$, and $\mathrm{Nb}$, shallow level of emplacement (see discussion on textural evidence below) and high temperature magma. More importantly all the samples plot in the A-type field in Whalen et al. (1987) plot (figure 10). The Atype granite from the study area is much more iron enriched (figure 11) and plots in the ferroan alkali-calcic and ferroan alkali fields of Frost et al. (2001). Calculated zircon saturation temperatures for the Besar magma range from $793^{\circ}$ to $806^{\circ} \mathrm{C}$ which suggest that these granites represent hightemperature partial melts. The temperature is consistent with high temperature partial melting of a felsic infracrustal source which is considered as one of the mechanisms to produce A-type magma (Jung et al. 1998; Chappell 1999). The temperature of the Besar magma was higher compared with the haplogranitic magma (Chappell 1999), which represents a low temperature hydrous silicate melt in equilibrium with quartz and feldspar (Tuttle and Bowen 1958). It is generally accepted that the high temperature of the magma may suggest that the A-type magma originated from partial melting of tonalitic sources, which could be one of the candidates for the Besar granite source rock (Clemens et al. 1986; Creaser et al. 1991; Patino Douce 1997).

The Besar granite texture shows an abundance of graphic intergrowth, especially in thin section, which indicates the shallow level emplacement of the magma (figure 6). Micrographic intergrowths of quartz and alkali feldspars are common in the A-type magma, which is supported by experimental work by Clemens et al. (1986). The work suggested that most A-type granites formed from relatively high temperature, water-undersaturated, completely molten (i.e., restite-free) magmas. The quartz and feldspar proportions that form the intergrowth texture are close to near minimumtemperature melt compositions for pressures of 100-200 MPa (Whalen et al. 1987). Granophyric intergrowths involve quartz and alkali feldspar, intergrown on scales from submicroscopic to 1 or $2 \mathrm{~mm}$. Approximately equal amounts of $\mathrm{SiO}_{2}$, $\mathrm{NaAlSi}_{3} \mathrm{O}_{8}$ and $\mathrm{KAlSi}_{3} \mathrm{O}_{8}$ participate in most of these intergrowths, which have a truly granitic composition. Granophyric intergrowths occur as mesostasis, ground mass, and megacrysts, and result from relatively rapid simultaneous growth of quartz and alkali feldspar from a melt, vapour, or devitrified glass.

In general, compared with the I-type granites, the A-type granites have higher HFSE, $\mathrm{Na}_{2} \mathrm{O}+$ $\mathrm{K}_{2} \mathrm{O}, \mathrm{Ge} / \mathrm{Mg}$ and $\mathrm{Ga} / \mathrm{Al}$, and lower $\mathrm{Eu}, \mathrm{CaO}$, and Sr (Loiselle and Wones 1979; Collins et al. 1982; Whalen et al. 1987). Highly felsic rocks of I-, Sand A-types often overlap in geochemical character as they converge towards the minimum temperature composition (e.g., Tuttle and Bowen 1958; Chappell 1999). Such rocks are very siliceous with 73-77\% $\mathrm{SiO}_{2}$, low $\mathrm{Al}_{2} \mathrm{O}_{3}, \mathrm{MgO}, \mathrm{CaO}$ and high $\mathrm{Na}_{2} \mathrm{O}, \mathrm{K}_{2} \mathrm{O}, \mathrm{SiO}_{2}, \mathrm{Al}_{2} \mathrm{O}_{3} \cdot \mathrm{Na}_{2} \mathrm{O}$ and $\mathrm{K}_{2} \mathrm{O}$ do not vary greatly in amount. This makes it difficult to discriminate most of the A-type granites consisting of highly felsic rocks. Several attempts have 

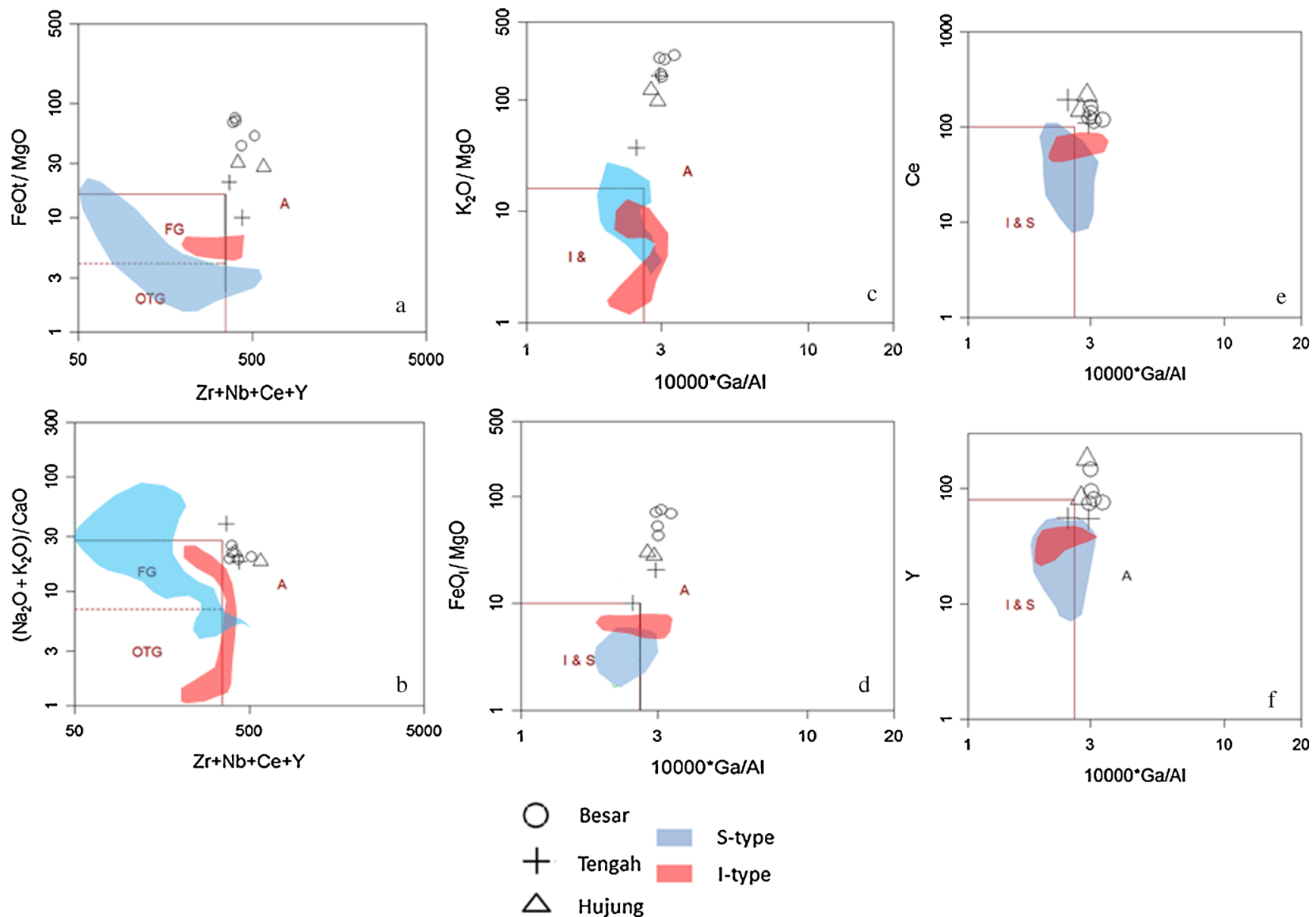

Figure 10. Various plot of the Besar granite samples (a) FeOt/MgO vs. $\mathrm{Zr}+\mathrm{Nb}+\mathrm{Ce}+\mathrm{Y} ;(\mathbf{b})\left(\mathrm{Na}{ }_{2} \mathrm{O}+\mathrm{K}_{2} \mathrm{O}\right) / \mathrm{CaO}$ vs. $\mathrm{Zr}+\mathrm{Nb}+\mathrm{Ce}+\mathrm{Y}$; (c) $\mathrm{K}_{2} \mathrm{O} / \mathrm{MgO}$ vs. $10000 * \mathrm{Ga} / \mathrm{Al}$; (d) $\mathrm{FeOt} / \mathrm{MgO}$ vs. $10000 * \mathrm{Ga} / \mathrm{Al}$; (e) Ce vs. $10000 * \mathrm{Ga} / \mathrm{Al}$ and (f) $\mathrm{Y}$ vs. $10000 * \mathrm{Ga} / \mathrm{Al}$ (Collins et al. 1982; Whalen et al. 1987). I: I-type, S: S-type, A: A-type; blue field: peninsular Malaysia I-type granite field; red field: peninsular Malaysia S-type field.

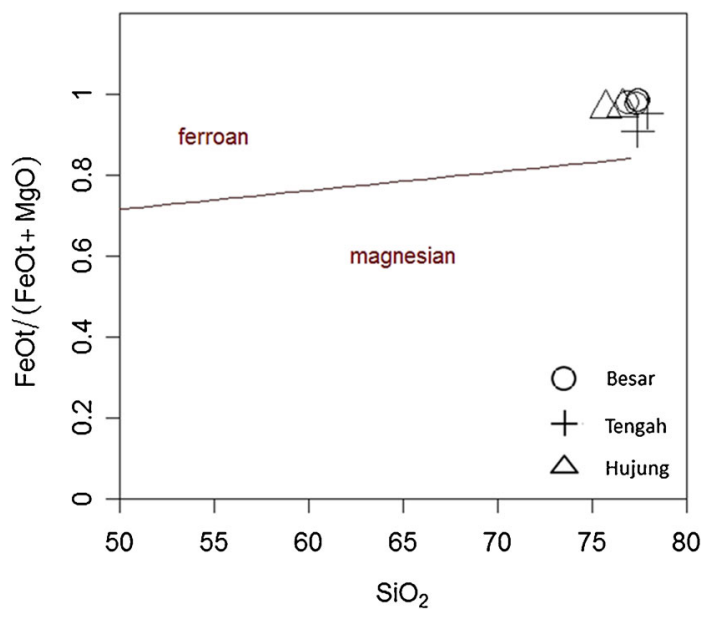

Figure 11. Fe index vs. $\mathrm{SiO}_{2}(\%)$ of the Besar group granites (Frost et al. 2011), boundary between ferroan and magnesian rocks from Frost and Frost (2008).

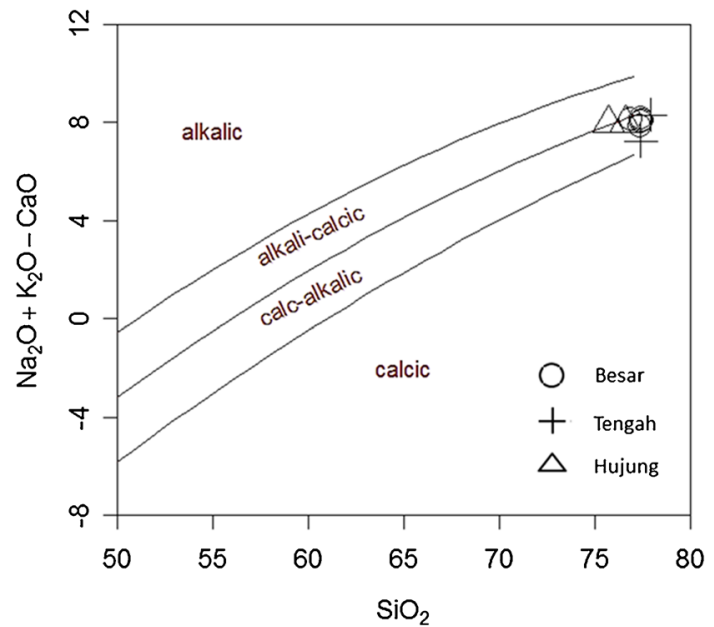

Figure 12. Modified alkali lime index $\left(\mathrm{Na}_{2} \mathrm{O}+\mathrm{K}_{2} \mathrm{O}-\mathrm{CaO}\right)$ vs. $\mathrm{SiO}_{2}(\%)$ of the Besar group garnites (Frost et al. 2011). Boundaries between calcic, calc-alkalic, alkali-calcic and alkali granitoids from Frost et al. (2001). 


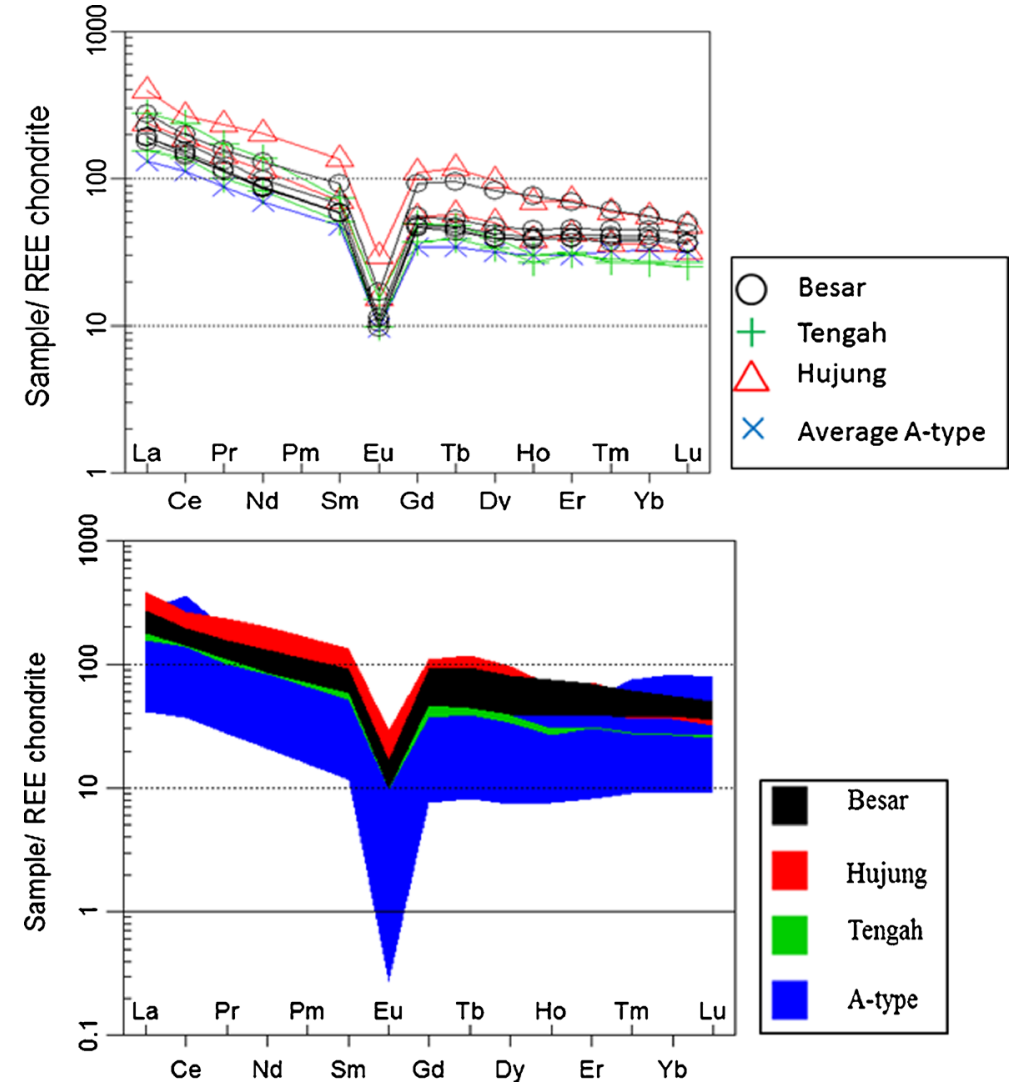

Figure 13. Primitive-mantle normalized spidergrams for the Besar granite. Elements are arranged in the order of decreasing incompatibility from left to right. The primitive-mantle values are from Sun and McDonough (1989).

Table 2. Major, trace element and REE data for the Besar, Tengah and Hujung granites and associated dykes.

\begin{tabular}{|c|c|c|c|c|c|c|c|c|c|}
\hline & $\mathrm{BH} 2$ & $\mathrm{BH} 4$ & BT6 & BT10 & BES1 & BES2 & BES3 & BES4 & BES6 \\
\hline Rock type & Gra & Gra & Gra & Gra & Gra & Gra & Gra & Gra & Gra \\
\hline Location & Hujung & Hujung & Tengah & Tengah & Besar & Besar & Besar & Besar & Besar \\
\hline \multicolumn{10}{|l|}{$\%$} \\
\hline $\mathrm{SiO}_{2}$ & 75.7 & 76.6 & 77.4 & 77.9 & 77.39 & 77.45 & 77.35 & 76.87 & 77.31 \\
\hline $\mathrm{TiO}_{2}$ & 0.14 & 0.17 & 0.21 & 0.16 & 0.09 & 0.09 & 0.09 & 0.11 & 0.08 \\
\hline $\mathrm{Al}_{2} \mathrm{O}_{3}$ & 12.08 & 12.1 & 11.72 & 12.21 & 12.14 & 11.98 & 12.01 & 12.44 & 12.05 \\
\hline $\mathrm{Fe}_{2} \mathrm{O}_{3}(\mathrm{~T})$ & 1.54 & 1.34 & 0.89 & 0.68 & 1.67 & 1.57 & 1.52 & 1.74 & 1.42 \\
\hline $\mathrm{MnO}$ & 0.03 & 0.17 & 0.02 & 0.01 & 0.02 & 0.02 & 0.03 & 0.02 & 0.02 \\
\hline $\mathrm{MgO}$ & 0.05 & 0.04 & 0.08 & 0.03 & 0.02 & 0.02 & 0.02 & 0.03 & 0.03 \\
\hline $\mathrm{CaO}$ & 0.46 & 0.38 & 0.42 & 0.22 & 0.34 & 0.39 & 0.44 & 0.43 & 0.44 \\
\hline $\mathrm{NaO}_{2}$ & 3.54 & 3.45 & 4.69 & 3.56 & 3.96 & 3.76 & 3.52 & 3.48 & 3.52 \\
\hline $\mathrm{K}_{2} \mathrm{O}$ & 4.9 & 4.88 & 2.97 & 4.97 & 4.57 & 4.73 & 4.99 & 5.12 & 4.8 \\
\hline $\mathrm{P}_{2} \mathrm{O}_{5}$ & 0.01 & 0.01 & 0.02 & 0.01 & 0.01 & 0.01 & 0.01 & 0.01 & 0.01 \\
\hline LOI & 0.58 & 0.63 & 0.6 & 0.52 & 0.49 & 0.49 & 0.64 & 0.66 & 0.60 \\
\hline Total & 99.03 & 99.77 & 99.02 & 100.1 & 100.8 & 100.6 & 100.7 & 100.5 & 100.3 \\
\hline \multicolumn{10}{|l|}{ ppm } \\
\hline $\mathrm{Ba}$ & 585 & 630 & 630 & 534 & 472 & 500 & 509 & 661 & 548 \\
\hline $\mathrm{Co}$ & 1.4 & 0.4 & 0.4 & 0.3 & 0.6 & 0.6 & 0.6 & 1 & 0.4 \\
\hline Cs & 4.4 & 3.2 & 1.6 & 2.6 & 3.8 & 3.7 & 4.2 & 4.3 & 3.5 \\
\hline $\mathrm{Ga}$ & 18.6 & 17.7 & 15.2 & 19.1 & 19.9 & 18.8 & 21.3 & 19.8 & 19.3 \\
\hline $\mathrm{Hf}$ & 6.6 & 6.2 & 5.9 & 7 & 7 & 6.7 & 6.8 & 6.7 & 7.1 \\
\hline $\mathrm{Nb}$ & 14.7 & 17.3 & 16 & 17.9 & 18.6 & 17.8 & 17.9 & 16.7 & 17 \\
\hline $\mathrm{Rb}$ & 212 & 208 & 115 & 196 & 210 & 222 & 246 & 223 & 225 \\
\hline
\end{tabular}


Table 2. (Continued.)

\begin{tabular}{|c|c|c|c|c|c|c|c|c|c|}
\hline $\begin{array}{l}\text { Rock type } \\
\text { Location }\end{array}$ & $\begin{array}{l}\text { BH2 } \\
\text { Gra } \\
\text { Hujung }\end{array}$ & $\begin{array}{l}\text { BH4 } \\
\text { Gra } \\
\text { Hujung }\end{array}$ & $\begin{array}{l}\text { BT6 } \\
\text { Gra } \\
\text { Tengah }\end{array}$ & $\begin{array}{l}\text { BT10 } \\
\text { Gra } \\
\text { Tengah }\end{array}$ & $\begin{array}{l}\text { BES1 } \\
\text { Gra } \\
\text { Besar }\end{array}$ & $\begin{array}{l}\text { BES2 } \\
\text { Gra } \\
\text { Besar }\end{array}$ & $\begin{array}{l}\text { BES3 } \\
\text { Gra } \\
\text { Besar }\end{array}$ & $\begin{array}{l}\text { BES4 } \\
\text { Gra } \\
\text { Besar }\end{array}$ & $\begin{array}{l}\text { BES6 } \\
\text { Gra } \\
\text { Besar }\end{array}$ \\
\hline $\mathrm{Sn}$ & 5 & 11 & 4 & 3 & 9 & 7 & 6 & 3 & 5 \\
\hline $\mathrm{Sr}$ & 34 & 30 & 53 & 27 & 26 & 23.5 & 25.1 & 36.1 & 26.6 \\
\hline $\mathrm{Ta}$ & 1.1 & 1.3 & 1 & 1.4 & 1.4 & 1.4 & 1.7 & 1.4 & 1.5 \\
\hline $\mathrm{Th}$ & 22 & 24 & 25 & 25 & 24 & 23 & 22 & 22 & 22 \\
\hline $\mathrm{U}$ & 5.6 & 5.8 & 3.7 & 6.1 & 6.6 & 6.4 & 5.9 & 6.4 & 7 \\
\hline W & 2.5 & 1.4 & 1.3 & 1.2 & 1.9 & 1.8 & 1.8 & 0.9 & 0.7 \\
\hline $\mathrm{Zr}$ & 171 & 162 & 172 & 186 & 181 & 181 & 176 & 190 & 181 \\
\hline $\mathrm{Y}$ & 179 & 83 & 55 & 54 & 81 & 75 & 76 & 148 & 95 \\
\hline Mo & 1.3 & 1.9 & 0.4 & 0.2 & 1.8 & 1.6 & 1.5 & 1.4 & 0.8 \\
\hline $\mathrm{Cu}$ & 7.1 & 9.5 & 4.4 & 2.1 & 6 & 3.8 & 5.5 & 5.3 & 3.4 \\
\hline $\mathrm{Pb}$ & 15.5 & 16.9 & 5.8 & 7.9 & 26.1 & 25 & 15.9 & 18.6 & 29 \\
\hline $\mathrm{Zn}$ & 150 & 93 & 37 & 37 & 79 & 51 & 58 & 40 & 57 \\
\hline $\mathrm{Ni}$ & 2.2 & 2.7 & 2.7 & 1.2 & 2.8 & 1.9 & 2.6 & 4.1 & 1.8 \\
\hline $\mathrm{La}$ & 121 & 73.1 & 86.7 & 48 & 55.3 & 59 & 59 & 85 & 70 \\
\hline $\mathrm{Ce}$ & 215 & 150 & 191 & 110 & 115 & 124 & 118 & 160 & 140 \\
\hline $\mathrm{Pr}$ & 28 & 17.4 & 21 & 12.2 & 13.6 & 14 & 14 & 19 & 16 \\
\hline $\mathrm{Nd}$ & 122 & 68.4 & 83 & 49.5 & 51 & 53 & 52 & 78 & 59 \\
\hline $\mathrm{Sm}$ & 26.4 & 13.7 & 14.5 & 9.9 & 12 & 11 & 11 & 18 & 13 \\
\hline $\mathrm{Eu}$ & 2.2 & 1.1 & 1.1 & 0.7 & 0.77 & 0.71 & 0.71 & 1.25 & 0.84 \\
\hline $\mathrm{Gd}$ & 29 & 14.1 & 12.8 & 9.54 & 12.6 & 12 & 12 & 24 & 14 \\
\hline $\mathrm{Tb}$ & 5.6 & 2.7 & 2.3 & 1.85 & 2 & 2 & 2 & 4 & 2 \\
\hline Dy & 31.1 & 16.1 & 12.7 & 10.8 & 14 & 13 & 13 & 26 & 15 \\
\hline Ho & 4.9 & 2.8 & 2.2 & 1.9 & 2.9 & 2.8 & 2.8 & 5 & 3 \\
\hline Er & 15 & 8.8 & 6.6 & 6.4 & 8.9 & 8.3 & 8.2 & 14.6 & 9.6 \\
\hline $\mathrm{Tm}$ & 1.9 & 1.2 & 0.9 & 0.9 & 1.3 & 1.3 & 1.2 & 1.9 & 1.5 \\
\hline $\mathrm{Yb}$ & 11.6 & 7.5 & 5.7 & 5.7 & 8.6 & 8 & 8 & 11.6 & 9.34 \\
\hline $\mathrm{Lu}$ & 1.6 & 1 & 0.9 & 0.9 & 1.2 & 1.2 & 1.2 & 1.6 & 1.4 \\
\hline $\mathrm{DF}$ & 94.2 & 95.01 & 94.89 & 97.04 & 95.64 & 95.47 & 95.16 & 94.74 & 94.78 \\
\hline $\mathrm{A} / \mathrm{CNK}$ & 1.01 & 1.04 & 1 & 1.05 & 1.01 & 1 & 1 & 1.03 & 1.02 \\
\hline Hy & 0.12 & 0.09 & 0.44 & 0.27 & 2.19 & 2.02 & 2.01 & 2.3 & 1.89 \\
\hline Mt & 1.3 & 1.13 & 0.58 & 0.42 & 0.28 & 0.25 & 0.25 & 0.28 & 0.23 \\
\hline $\mathrm{Ilm}$ & 0.26 & 0.32 & 0.39 & 0.3 & 0.17 & 0.17 & 0.17 & 0.20 & 0.15 \\
\hline $\mathrm{N}+\mathrm{K}$ & 8.37 & 8.32 & 8.53 & 8.59 & 8.53 & 8.49 & 8.51 & 8.6 & 8.32 \\
\hline $\mathrm{F} / \mathrm{F}+\mathrm{M}$ & 0.99 & 0.95 & 1 & 0.98 & 0.99 & 0.99 & 0.99 & 0.98 & 0.98 \\
\hline $\mathrm{N}+\mathrm{K}-\mathrm{C}$ & 8.19 & 8.32 & 8.49 & 8.55 & 8.19 & 8.10 & 8.07 & 8.17 & 7.88 \\
\hline $\mathrm{TE}_{1,3}$ & 1.05 & 1.09 & 1.09 & 1.05 & 1.03 & 1.03 & 1.0 & 1.0 & 1.02 \\
\hline
\end{tabular}

DF: Differentiation index; A/CNK: $\mathrm{Mol} \mathrm{Al}_{2} \mathrm{O}_{3} / \mathrm{Na}_{2} \mathrm{O}+\mathrm{K}_{2} \mathrm{O}+\mathrm{CaO} ; \mathrm{Hy}$ : Hypersthene normative; Mt: Magnetite normative; Ilm: Ilmenite normative; n.d: not determined: LOI: Loss on ignition; $\mathrm{Na}+\mathrm{K}: \mathrm{Na}_{2} \mathrm{O}+\mathrm{K}_{2} \mathrm{O} ; \mathrm{F} / \mathrm{F}+\mathrm{M}: \mathrm{FeOt} /(\mathrm{FeOt}+\mathrm{MgO})$; $\mathrm{N}+\mathrm{K}-\mathrm{C}: \mathrm{Na}_{2} \mathrm{O}+\mathrm{K}_{2} \mathrm{O}-\mathrm{CaO}, \mathrm{TE}_{1,3}$ : degree of tetrad effect.

been made to discriminate A-types from the others (e.g., Collins et al. 1982; Whalen et al. 1987; Sylvester 1989; Eby 1990, 1992; Frost and Frost 2011). The $\mathrm{SiO}_{2}$ content of the Besar granite is generally similar to the haplogranite from the Lachlan Fold Belt (Chappell 1999). The major element content of the Lachlan Fold Belt is characterized by 73 to $77 \% \quad \mathrm{SiO}_{2}$, low $\mathrm{Al}_{2} \mathrm{O}_{3}$ $(<13 \%)$, low $\mathrm{MgO}$ (0.04 to 0.79\%), $\mathrm{CaO}(0.32$ to $1.68 \%$ ), and transition elements (see table 2 in Chappell 1999). Interestingly, $\mathrm{Al}_{2} \mathrm{O}_{3}, \mathrm{MgO}$, and $\mathrm{CaO}$ contents of the Besar granite are much lower compared with the haplogranite from the Lachlan Fold belt, i.e., $\mathrm{Al}_{2} \mathrm{O}_{3}(<12.5 \%), \mathrm{MgO}$ $(0.0-0.08 \%), \mathrm{CaO}(0.0-0.46 \%)$ respectively. This large amount of high $\mathrm{SiO}_{2}$ granite may imply that the source rock was relatively homogeneous and not highly variable in composition; otherwise, the anatexsis would have produced large heterogeneities. 


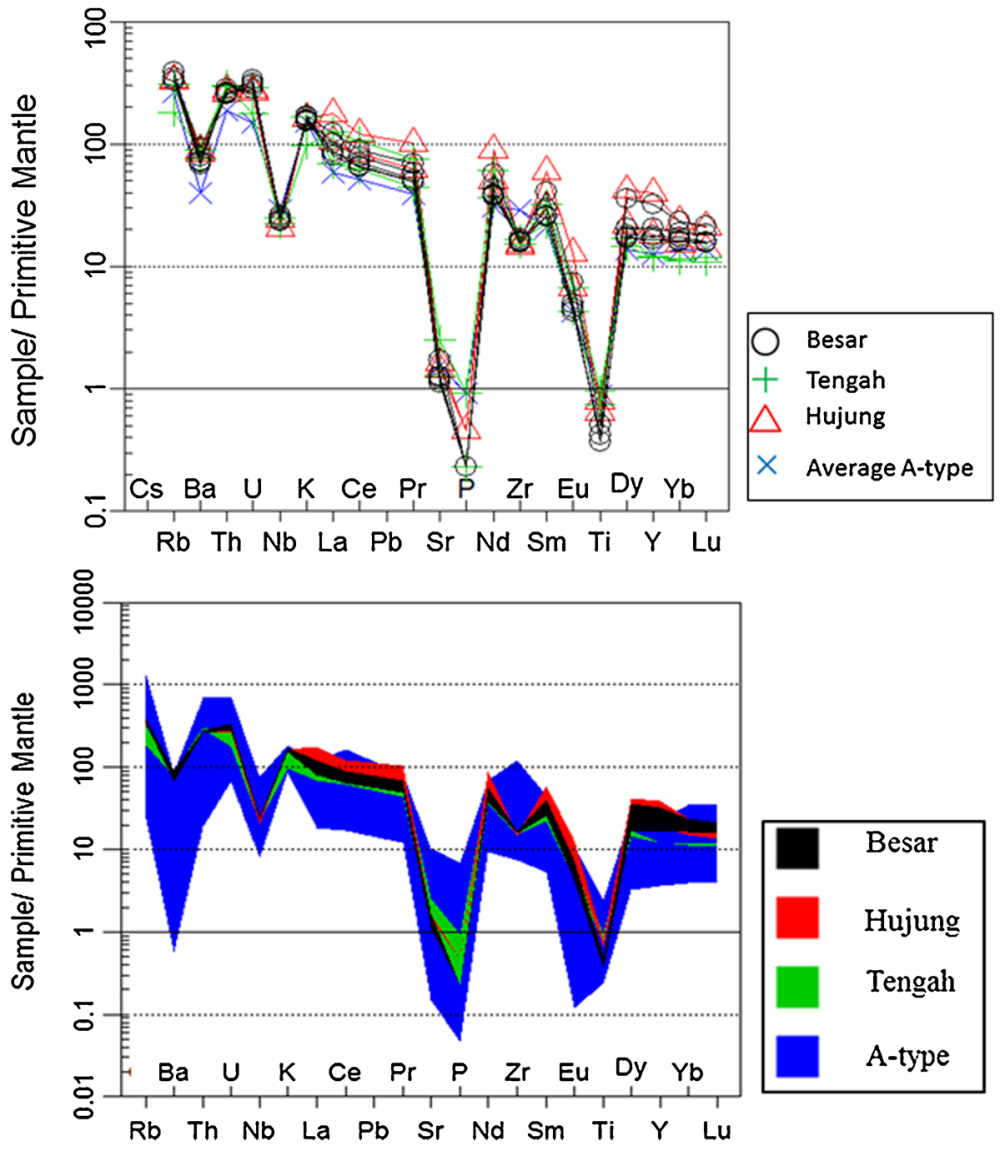

Figure 14. Rock chondrite REE profile of the Besar granite. Sample and its $\mathrm{SiO}_{2}$ content are shown in the legend.

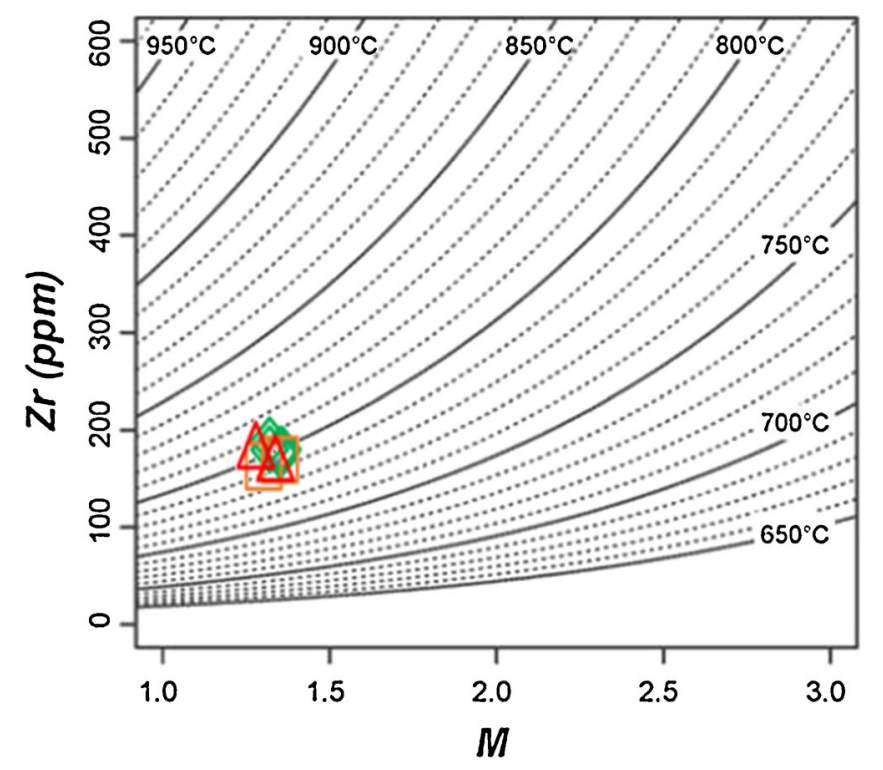

Figure 15. Zr (ppm) vs. M $[(100 \mathrm{Na}+\mathrm{K}+2 \mathrm{Ca}) /(\mathrm{Al} . \mathrm{Si})]$ for the granite from Besar Island Group.

It is generally accepted that the subduction of Paleo-Tethys oceanic floor beneath Indo-China terrane started in Early Permian (Metcalfe 2000; Sone and Metcalfe 2008) (figure 17). The subduction caused an early magmatism along the esastern margin of the Indo-China terrane which resulted in the development of the Sukhotai island arc system (Sone and Metcalfe 2008; Metcalfe 2013). At the same time (most earliest Permian), convection astenosphere driven by the downward drag of the down going oceanic slab caused a spreading and produced the back arc basin behind the magmatic arc (Sukhotai Arc) (figure 16). Regional extension occurs when continental lithosphere breaks in response to long-lived mantle perturbations, when hot mantle rises and erodes continental lithosphere, leading to full-scale rifting (e.g., Santosh et al. 2010). Sone and Metcalfe (2008) and Metcalfe (2013) suggested that these back arc basins now represent Nan suture and Sra Kaeo suture of central and southern Thailand, respectively (see figure 17 for the location of both sutures). According to Sone and Metcalfe (2008), these two sutures (Nan and Sra Kaeo) contain Permian melanges and ophiolites (e.g., Hada et al. 1999). Metcalfe (2013) suggested that these back arc sutures can be traced southward to the eastern offshore Malay 


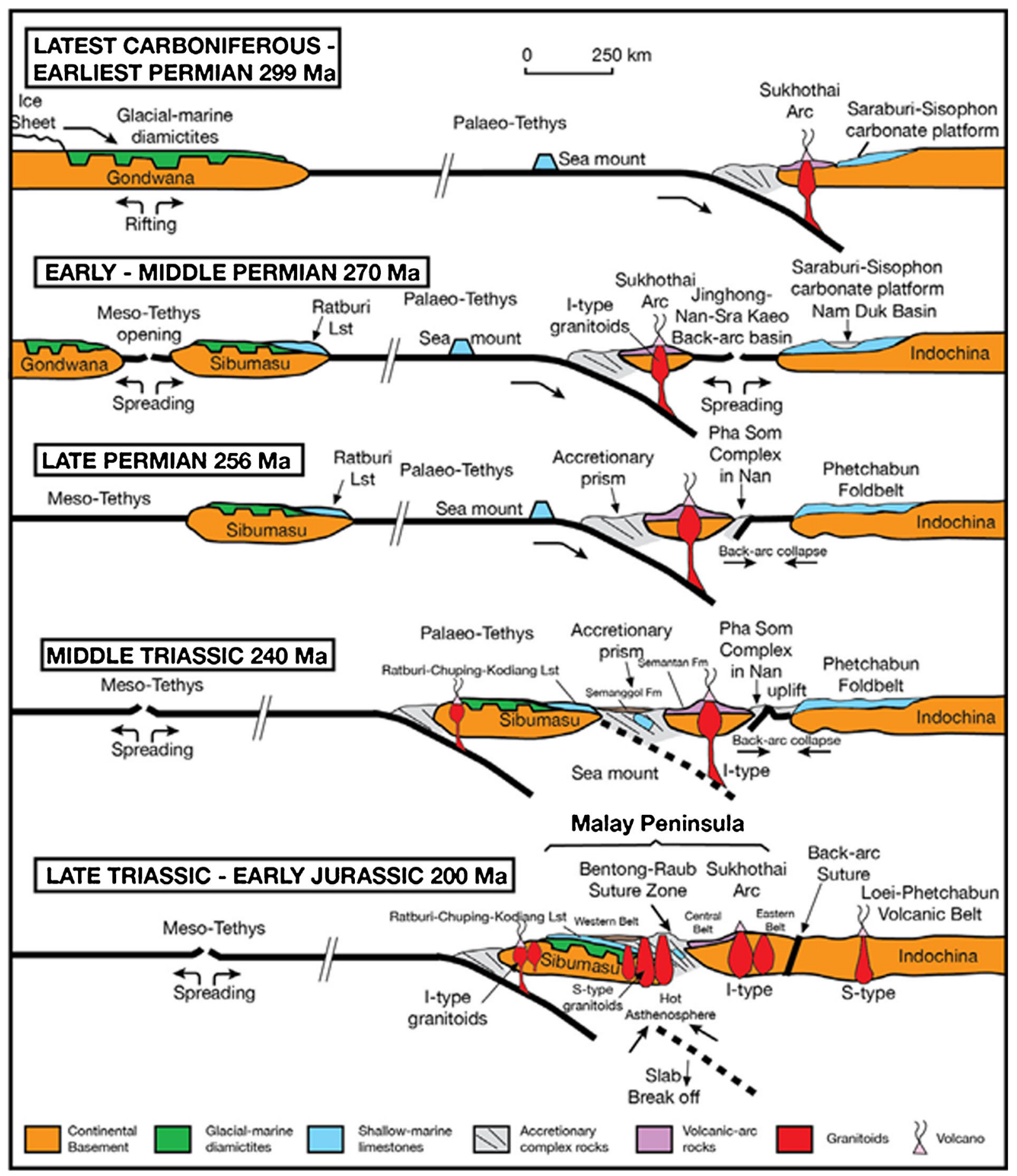

Figure 16. Diagram showing the tectonic evolution of Sundaland (Thailand-Malay peninsula) and evolution of the Sukhothai Arc System during Late Carboniferous-Early Jurassic times. Note also the formation of back arc basin in the early to Middle Permain - Jinghong-Nan-Sra Kaeo Back arc basin. Diagram taken from Metcalfe (2013).

peninsular, where the study area is located. Evidence of highly deformed carboniferous continental margin sequences along the eastern part of Malay peninsular may be the expression of orogenic deformation related to the closure of the back arc basin (Metcalfe 2013). The extension causes the hot asthenosphere rises, undergoes decompression melting, and induces melting in the overlying continental crust. Both regional extensional regimes have been proposed as likely tectonic regimes for A-type granites and related rocks. 


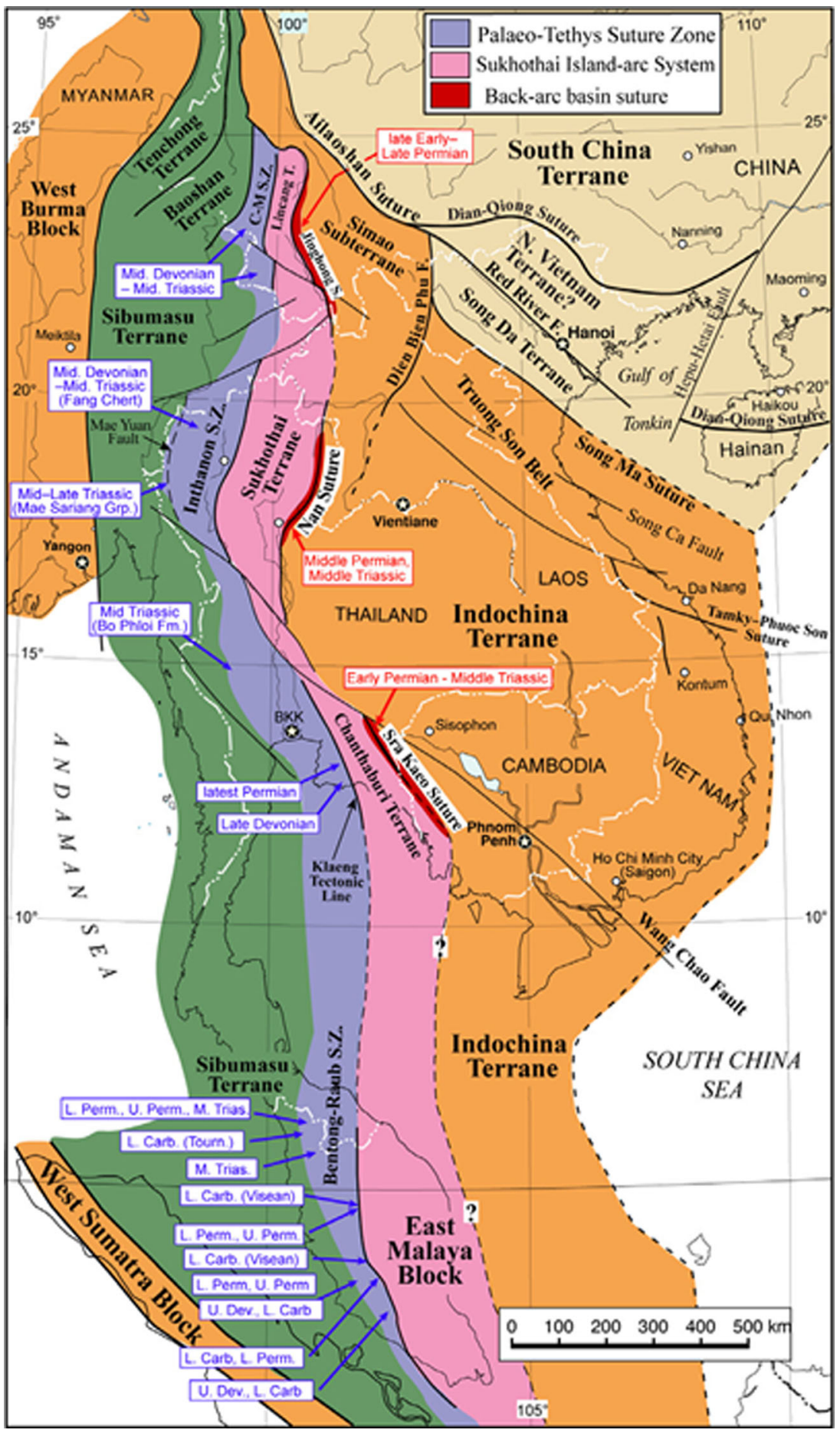

Figure 17. Tectonic subdivision of mainland SE Asia Sundaland showing the Sukhothai Arc terranes and bounding PalaeoTethys and back-arc suture zones. Diagram taken from Metcalfe (2013).

\section{Conclusion}

This paper reports the first possible occurrence of A-type granite from peninsular Malaysia. The granite occurs in the Besar, Tengah, and Hujung islands off the southeastern part of peninsular Malaysia. The granite is characterized by high $\mathrm{SiO}_{2}(>76 \%)$ and a texture dominated by granophyric intergrowth. The granite is mildly peraluminous, with a high calculated zircon temperature, high $\mathrm{Ga}, \mathrm{Fe}_{\mathrm{T}} / \mathrm{MgO}$, low $\mathrm{P}, \mathrm{Sr}, \mathrm{Ti}, \mathrm{CaO}$, and $\mathrm{Nb}$ and can be classified as A-type granite. The granite is characterized by shallow-level emplacement texture such as abundant granophyric intergrowth, which is common in A-type granite elsewhere. 
Geochemical data showed that the granite is highly felsic A-type granitic rock with $\mathrm{SiO}_{2}$ ranging from $76.24 \%$ to $77.90 \%$ (differentiation index $=94.2-97.84)$. The granite has normative hypersthene $(0.09-0.44 \%)$ and high alkali content (7.88-8.59 wt\%). Calculated zircon saturation temperatures for the Besar magma ranging from $793^{\circ}$ to $806^{\circ} \mathrm{C}$ is consistent with high temperature partial melting of a felsic infracrustal source, which is taken as one of the mechanisms to produce Atype magma. REE and spidergram patterns are consistent with an A-type magma. The granite is characterized by shallow level emplacement texture such as abundant granophyric intergrowth. The occurrence of A-type granite can be related to the extensional back arc basin in the Indo-China terrane during the earliest Permian.

\section{Acknowledgements}

This work presents a preliminary study of the Johor Island, southeast of peninsular Malaysia. The field work on these islands was done by AAG with the help from FI, WAWI, QLX, KKN, AJ, MHR, and MFAB. The geochemical work sponsored by University Malaya Research Grant No. RG041/09AFR and University Malaya PPP Grant No. PV087/2012A. Geochronological analyses were done in Department of Geosciences, National Taiwan University (under the supervision of SLC and YML) and partly sponsored by High Impact Research Grant UM/MOHE No. (UMC/HIR/MOHE/SC/27) and Post Graduate Research Grant PG095-2012B. AAG acknowledge NSC Grant No. 101-2811-M-002-133 (Republic of China) for fellowship in the Department of Geoscience, National Taiwan University, where most of the manuscript was written. The manuscript benefited from comments and suggestions by Dr N A Majid and the two reviewers are greatly acknowledged.

\section{References}

Bonin B 2007 A-type granites and related rocks: Evolution of a concept, problems and prospects; Lithos 97 1-29.

Bonin B, Platevoet B and Vialette Y 1987 The geodynamic significance of alkaline magmatism in the western Mediterranean compared with West Africa; In: African Geology Reviews (eds) Bowden P and Kinnaird J A, Geol. J. 22 361-387.

Bonin B, Azzouni-Sekkal A, Bussy F and Ferrag S 1998 Alkalicalcic and alkaline post-orogenic (PO) granite magmatism: Petrologic constraints and geodynamic settings; Lithos 45 45-70.

Bonin B, Ethien R, Gerbe M C, Cottin J Y, Féraud G, Gagnevin D, Giret A, Michon G and Moine B 2004 The Neogene to Recent Rallier-du-Baty nested ring complex,
Kerguelen Archipelago (TAAF, Indian Ocean): Stratigraphy revisited, implications for cauldron subsidence; In: Physical Geology of High-Level Magmatic Systems (eds) Breitkreuz C and Petford N, Geol. Soc. London, Spec. Publ. 234 125-149.

Capaldi G, Chiesa S, Manetti P, Orsi G and Poli G 1987 Tertiary anorogenic granites of the western border of the Yemen Plateau; Lithos 20 433-444.

Chappell B W 1999 Aluminium saturation in I- and S-type granites and the characterization of fractionated haplogranites; Lithos 46 535-551.

Christiansen R L, Foulger G R and Evans J R 2002 Uppermantle origin of the Yellowstone hotspot; Geol. Soc. Am. Bull. 114 1245-1256.

Clemens J D, Holloway J R and White A J R 1986 Origin of an A-type granite: Experimental constraints; $\mathrm{Am}$. Mineral. 71 317-324.

Cobbing E J, Pitfield P E J, Darbyshire D P F and Mallick D I J 1992 The granites of the south-east Asian tin belt; Overseas Memoir 10, British Geological Survey, 368p.

Collins W J, Beams S D, White A J R and Chappel B W 1982 Nature and origin of A-type granites with particular reference to southeastern Australia; Contrib. Mineral. Petrol. 80 189-200.

Creaser R A, Price R C and Wormald R J 1991 A-type granites revisited: Assessment of a residual-source model; Geology 19 163-166.

Eby G N 1990 The A-type granitoids: A review of their occurrence and chemical characteristics and speculations on their petrogenesis; Lithos 26 115-134.

Eby G N 1992 Chemical subdivision of the A-type granitoids: Petrogenetic and tectonic implications; Geology 20 641-644.

Frost B R and Frost C D 2008 A geochemical classification for feldspathic igneous rocks; J. Petrol. 49 1955-1969.

Frost C D and Frost B R 2011 On Ferroan (A-type) granitoids: Their compositional variability and modes of origin; J. Petrol. 52(1) 39-53.

Frost B R, Barnes C G, Collins W J, Arculus R J, Ellis D J and Frost C D 2001 A geochemical classification for granitic rocks; J. Petrol. 42 2033-2048.

Gagnevin D, Ethien R, Bonin B, Moine B, Féraud G, Gerbe M C, Cottin J Y, Michon G, Tourpin S, Mamias G, Perrache C and Giret A 2003 Open-system processes in the genesis of silica over saturated alkaline rocks of the Rallier-du-Baty Peninsula, Kerguelen Archipelago (Indian Ocean); J. Volcanol. Geotherm. Res. 123 267-300.

Ghani A A 2000a Mesozoic mafic dykes from Eastern Belt (Part 1): Textural study of the older dykes; Proc. Dynamic Stratigraphy and Tectonics of peninsular Malaysia (3rd seminar), The Mesozoic of peninsular Malaysia, pp. 48-54.

Ghani A A 2000b Mesozoic mafic dykes from Eastern Belt (Part 2): Geochemistry of the younger dykes; Proc. Dynamic Stratigraphy and Tectonics of peninsular Malaysia (3rd seminar), The Mesozoic of peninsular Malaysia, pp. 96-105.

Ghani A A 2006 Batuan volkanik dari Pulau Tinggi dan Pulau Sibu Johor; Geol. Soc. Malaysia Bull. 52 63-66.

Ghani A A 2008 Volcanic rock from the Tioman island: Geochemistry and petrography; In: Natural History of the Tioman group of islands (eds) Phang S M, Amri A Y, Jillian O L S and Mydin A J, Institute of Ocean and Earth Sciences Monograph Series 1, University Malaya, pp. 11-13.

Ghani A A 2009 Plutonism; In: Geology of Peninsular Malaysia (eds) Hutchison C S and Tan D N K, University of Malaya/Geological Society of Malaysia, Kuala Lumpur, pp. 211-231. 
Ghani A A and Mohd Farid Abu Bakar 2004 Geology and granite petrology of the Besar island, Johore; Geol. Soc. Malaysia Bull. 48 61-64.

Ghani A A and Azmi A R 2008 Petrology and geochemistry of the plutonic rock from Tioman island; In: Natural History of the Tioman group of Islands (eds) Phang S M, Amri A Y, Jillian O L S and Mydin A J, Institute of Ocean and Earth Sciences Monograph Series 1, University Malaya, pp. 11-13.

Ghani A A, Shaarani N A and Anuar Hairul Azhar A 1999 Field relation of granite-volcanics interaction at Tioman island, Pahang: More evidence for the occurrence of an older granite in the island; Warta Geology 25(5) 229-233.

Ghani A A, Searle M, Robb L and Chung S-L 2013a Transitional I-S type characteristics in the Main Range Granite, peninsular Malaysia; J. Asian Earth Sci. 76 225-240.

Ghani A A, Lo C-H and Chung S-L 2013b Basaltic dykes of the eastern belt of peninsular Malaysia: The effects of the difference in crustal thickness of Sibumasu and IndoChina; J. Asian Earth Sci. 77 127-139.

Ghani A A, Yusoff I, Amir Hassan M H and Ramli R 2013c Geochemical study of volcanic and associated granitic rocks from Endau Rompin, Johor, peninsular Malaysia; J. Earth Syst. Sci. 122(1) 65-78.

Ghani A A, Lo C-H and Chung S-L 2014 Geochronology of volcanic and plutonic rocks from the islands off Pahang and east Johor, peninsular Malaysia; Proceedings National Geoscience Conf. 2014, Geological Society of Malaysia, 99p.

Govindaraju K, Potts P J, Webb P C and Waston J S 1994 Report on Whin Sill dolerite WS-S from England and Pitscuriemicrogabbro PM-S from Scotland: Assessment by 104 international laboratories; Geostandards Newsletter 18 211-300.

Hada S, Bunopas S, Ishii K and Yoshikura S 1999 Rift-drift history and the amalgamation of Shan-Thai and Indochina/East Malaya Blocks. In: Gondwana dispersion and Asian accretion (eds) Metcalfe I, Final Results Volume for IGCP Project 321 Balkema, Rotterdam 67-87.

Haile N S, Beckinsale R D, Chakraborty K R, Hanif H and Hardjono T 1983 Paleomagnetism, geochronology and petrology of the dolerite dykes and basaltic lavas from Kuantan, west Malaysia; Geol. Soc. Malaysia Bull. 16 71-85.

Hutchison C S 1973 Tectonic evolution of Sundaland: A phanerozoic synthesis; Geol. Soc. Malaysia Bull. 6 797806.

Hutchison C S 1977 Granite emplacement and tectonic subdivision of peninsular Malaysia; Geol. Soc. Malaysia Bull. 9 187-207.

Irber W 1999 The lanthanide tetrad effect and its correlation with $\mathrm{K} / \mathrm{Rb}, \mathrm{Eu} / \mathrm{Eu}, \mathrm{Sr} / \mathrm{Eu}, \mathrm{Y} / \mathrm{Ho}$, and $\mathrm{Zr} / \mathrm{Hf}$ of evolving peraluminous granite suite; Geochim. Cosmochim. Acta 63 489-508.

Jahn B M, Wu F Y, Capdevila R, Martineau F, Zhao Z H and Wang Y X 2001 Highly evolved juvenile granites with tetrad REE patterns: The Woduhe and Baerzhe granites from the great Xing'an Mountains in NE China; Lithos 59 171-198.

Johnson C M, Czamanske G K and Lipman P W 1989 Geochemistry of intrusive rocks associated with the Latir volcanic field, New Mexico, and contrasts between evolution of plutonic and volcanic rocks; Contrib. Mineral. Petrol. 103 90-109.

Jung S, Mezger K and Hoernes S 1998 Petrology and geochemistry of syn- to post-collisional metaluminous A-type granites - a major and trace element and $\mathrm{Nd}-\mathrm{Sr}-\mathrm{Pb}-$ O-isotope study from the Proterozoic Damara Belt, Namibia; Lithos 45 147-175.
Kawabe I 1995 Tetrad effects and fine structures of REE abundance patterns of granitic and rhyolitic rocks: ICPAES determinations of REE and Y in eight GSJ reference rocks; Geochem J. 29 213-230.

Kerr A and Fryer B J 1993 Nd isotope evidence for crust mantle interaction in the generation of A-type granitoid suites in Labrador, Canada; Chem. Geol. 104 39-60.

Key R M 1989 A note on the Jibisa Ring Complex of northern Kenya; J. African Earth Sci. 8 113-125.

Khoo T T 1974 A glimpse at the geology of Pulau Tioman; In: The Natural History of Pulau Tioman (eds) Lee D W and Stone B C, Merlin Samudera, pp. 5-17.

King P L, White A J R and Chappell B W 1997 Characterization and origin of aluminous A-type granites of the Lachlan Fold Belt, southeastern Australia; J. Petrol. 36 371-391.

Lauri L S, Rämö O T, Huhma H and Mänttäri Räsänen J 2006 Petrogenesis of silicic magmatism related to the $\sim 2.44$ Ga rifting of Archean crust in Koillismaa, eastern Finland; Lithos 86 137-166.

Liew T C 1983 Petrogenesis of the peninsular Malaysia granitoid batholith; Unpubl. PhD thesis, Australia Nat. University.

Liew T C and Mc Culloch M T 1985 Genesis of granitoid batholiths of peninsular Malaysia and implication for models of crustal evolution: Evidence from $\mathrm{Nd}-\mathrm{Sr}$ isotopic and $\mathrm{U}-\mathrm{Pb}$ zircon study; Geochim. Cosmochim. Acta 49 $587-600$.

Liew T C and Page R W 1985 U-Pb zircon dating of granitoid plutons from the west coast province of peninsular Malaysia; J. Geol. Soc. 142 515-526.

Loiselle M C and Wones D R 1979 Characteristics and origin of anorogenic granites; Abstracts of papers to be presented at the Annual Meetings of the Geological Society of America and Associated Societies, San Diego, California, November 5-8, vol. 11, p. 468.

Mahood G A and Hildreth W 1986 Geology of the peralkaline volcano at Pantelleria, Strait of Sicily; Bull. Volcanol. 48 143-172.

Metcalfe I 2000 The Bentong-Raub suture zone; J. Asian Earth Sci. 18 691-712.

Metcalfe I 2013 Tectonic evolution of Peninsular Malaysia; J. Asian Earth Sci. 76 195-213.

Mitchell A H G 1977 Tectonic settings for the emplacement of the Southeast Asian tin granites; Geol. Soc. Malaysia Bull. 9 123-140.

Mohd Basri A Hamid, Asmuri Mohd Marzuki, Ghani A A, Umor Mohd Rozi and Ismail M A 2002 Petrology of igneous rocks from the Pemanggil island; Geol. Soc. Malaysia Bull. 45 247-251.

Monecke T, Dulski P and Kempe U 2007 Origin of convex tetrads in rare earth element patterns of hydrothermally altered siliceous igneous rocks from the Zinnwald Sn-W deposit, Germany; Geochim. Cosmochim. Acta 71 335-353.

Nironen M, Elliott B A and Rämö O T 2000 1.88-1.87 Ga postkinematic intrusions of the Central Finland Granitoid Complex: A shift from C-type to A-type magmatism during lithospheric convergence; Lithos 53 37-58.

Oliver J G H, Khin Z, Hotson M, Meffre S and Manka T $2013 \mathrm{U}-\mathrm{Pb}$ zircon geochronology of Early Permian to Late Triassic rocks from Singapore and Johor: A plate tectonic reinterpretation; Gondwana Res., doi: 10.1016/j.gr.2013.03.019.

Orajaka I P 1986 Geochemistry of Kaffo Valley albiteriebeckite-granite, Liruei granite ring-complex, northern Nigeria; Chem. Geol. 56 85-92.

Patino Douce A E 1997 Generation of metaluminous A-type granites by low-pressure melting of calc-alkaline granitoids; Geology 25 743-746. 
Pearce J A, Harris N B W and Tindle A G 1984 Trace element discrimination diagrams for the tectonic interpretation of granitic rocks; J. Petrol. 25 956-983.

Rämö O T and Haapala I 1995 One hundred years of rapakivi granites; Mineral. Petrol. 52 129-185.

Santosh M, Maryuama S, Komiya T and Yamamoto S 2010 Orogens in the evolving Earth: From surface continents to 'lost continents' at the core-mantle boundary; In: The evolving continents: Understanding processes of continental growth (eds) Kusky T M, Zhai M-G and Xiao W, Geol. Soc. London, Spec. Publ. 338 77-116.

Searle M P, Whitehouse M J, Robb L J, Ghani A A, Hutchison C S, Sone M, Ng S W P, Roselee M H, Chung S L and Oliver G J H 2012 Tectonic evolution of Sibumasu-Indochina terrane collision zone in Thailand and Malaysia - constraints from new $\mathrm{U}-\mathrm{Pb}$ zircon chronology of SE Asian tin granitoids; J. Geol. Soc. 169 489-500.

Smith I E M, Chappell B W, Ward G K and Freeman R S 1977 Peralkaline rhyolites associated with andesitic arcs of the southwest Pacific; Earth Planet. Sci. Lett. 37 $230-236$.

Sone M and Metcalfe I 2008 Parallel Tethyan Sutures in mainland SE Asia: New insights for Palaeo-Tethys closure; CompteRendus Geosci. 340 166-179.

Sun S S and McDonough W F 1989 Chemical and isotopic systematic of oceanic basalts: Implication for mantle composition and processes; In: Magmatism in ocean basin (eds) Saunders A D and Norry M J, Geol. Soc. London, Spec. Publ. 42 315-345.

Sylvester P J 1989 Post-collisional alkaline granites; J. Geol. $97261-280$.

Taylor R P, Strong D F and Fryer B J 1981 Volatile control of contrasting trace element distributions in peralkaline granitic and volcanic rocks; Contrib. Mineral. Petrol. 77 267-271.

Tucker R D, Ashwal L D and Torsvik T H 2001 U-Pb geochronology of Seychelles granitoids: A Neoproterozoic continental arc fragment; Earth Planet. Sci. Lett. 187 27-38.

Turner S P, Foden J D and Morrison R S 1992 Derivation of some A-type magmas by fractionation of basaltic magma: An example from the Padthaway Ridge, south Australia; Lithos 28 151-179.

Tuttle O F and Bowen N L 1958 Origin of granite in the light of experimental studies in the system $\mathrm{NaAlSi}_{3} \mathrm{O}_{8}-$ $\mathrm{KAlSi}_{3} \mathrm{O}_{8}-\mathrm{H}_{2} \mathrm{O}$; Geol. Soc. Am. Memoir $\mathbf{7 4} 153$.

Watson E B and Harrison T M 1983 Zircon saturation revisited: Temperature and composition effects in a variety of crustal magma types; Earth Planet. Sci. Lett. 64 295-304.

Whalen J B, Currie K L and Chappell B W 1987 A type granites: Geochemical characteristics, discrimination and petrogenesis; Contrib. Mineral. Petrol. 95 407-419.

Wu F Y, Sun D Y, Jahn B M and Wilde S 2004 A Jurassic garnet-bearing granitic pluton from NE China showing tetrad REE patterns; J. Asian Earth Sci. 23 731-744. 